University of New Hampshire

University of New Hampshire Scholars' Repository

Winter 1975

\title{
SENSITIVITY OF MARINE CILIATES (PROTOZOA, CILIOPHORA) TO HIGH THERMAL STRESS
}

EDWIN ALBERTO MARTINEZ

Follow this and additional works at: https://scholars.unh.edu/dissertation

\section{Recommended Citation}

MARTINEZ, EDWIN ALBERTO, "SENSITIVITY OF MARINE CILIATES (PROTOZOA, CILIOPHORA) TO HIGH THERMAL STRESS" (1975). Doctoral Dissertations. 1106.

https://scholars.unh.edu/dissertation/1106

This Dissertation is brought to you for free and open access by the Student Scholarship at University of New Hampshire Scholars' Repository. It has been accepted for inclusion in Doctoral Dissertations by an authorized administrator of University of New Hampshire Scholars' Repository. For more information, please contact Scholarly.Communication@unh.edu. 


\section{INFORMATION TO USERS}

This material was produced from a microfilm copy of the original document. While the most advanced technological means to photograph and reproduce this document have been used, the quality is heavily dependent upon the quality of the original submitted.

The following explanation of techniques is provided to help you understand markings or patterns which may appear on this reproduction.

1. The sign or "target" for pages apparently lacking from the document photographed is "Missing Page(s)". If it was possible to obtain the missing page(s) or section, they are spliced in to the film along with adjacent pages. This may have necessitated cutting thru an image and duplicating adjacent pages to insure you complete continuity.

2. When an image on the film is obliterated with a large round black mark, it is an indication that the photographer suspected that the copy may have moved during exposure and thus cause a blurred image. You will find a good image of the page in the adjacent frame.

3. When a map, drawing or chart, etc., was part of the material being photographed the photographer followed a definite method in "sectioning" the material. It is customary to begin photoing at the upper left hand corner of a large sheet and to continue photoing from left to right in equal sections with a small overlap. If necessary, sectioning is continued again - beginning below the first row and continuing on until complete.

4. The majority of users indicate that the textual content is of greatest value, however, a somewhat higher quality reproduction could be made from "photographs" if essential to the understanding of the dissertation. Silver prints of "photographs" may be ordered at additional charge by writing the Order Department, giving the catalog number, title, author and specific pages you wish reproduced.

5. PLEASE NOTE: Some pages may have indistinct print. Filmed as received.

Xerox University Microfilms 


$$
76-11,682
$$

MARTINEZ, Edwin Alberto, 1942-

SENSITIVITY OF MARINE CILIATES (PROTOZOA, CILIOPHORA) TO HIGH THERMAL STRESS.

University of New Hampshire, Ph.D., 1975 Zoology

Xerox University Microfilms, Ann Arbor, Michigan 48106 


\title{
SENSITIVITY OF MARINE CILIATES (PROTOZOA, CILIOPHORA) TO HIGH THERMAL STRESS
}

\author{
by \\ EDWIN A. MARTINEZ \\ B.S., The City College of New York, 1965 \\ M.A., The City College of New York, 1972
}

\begin{abstract}
A THESIS
Submitted to the University of New Hampshire

In Partial Fulfillment of

The Requirements for the Degree of
\end{abstract}

\author{
Doctor of Philosophy \\ Graduate School \\ Department of Zoology \\ December, 1975
}




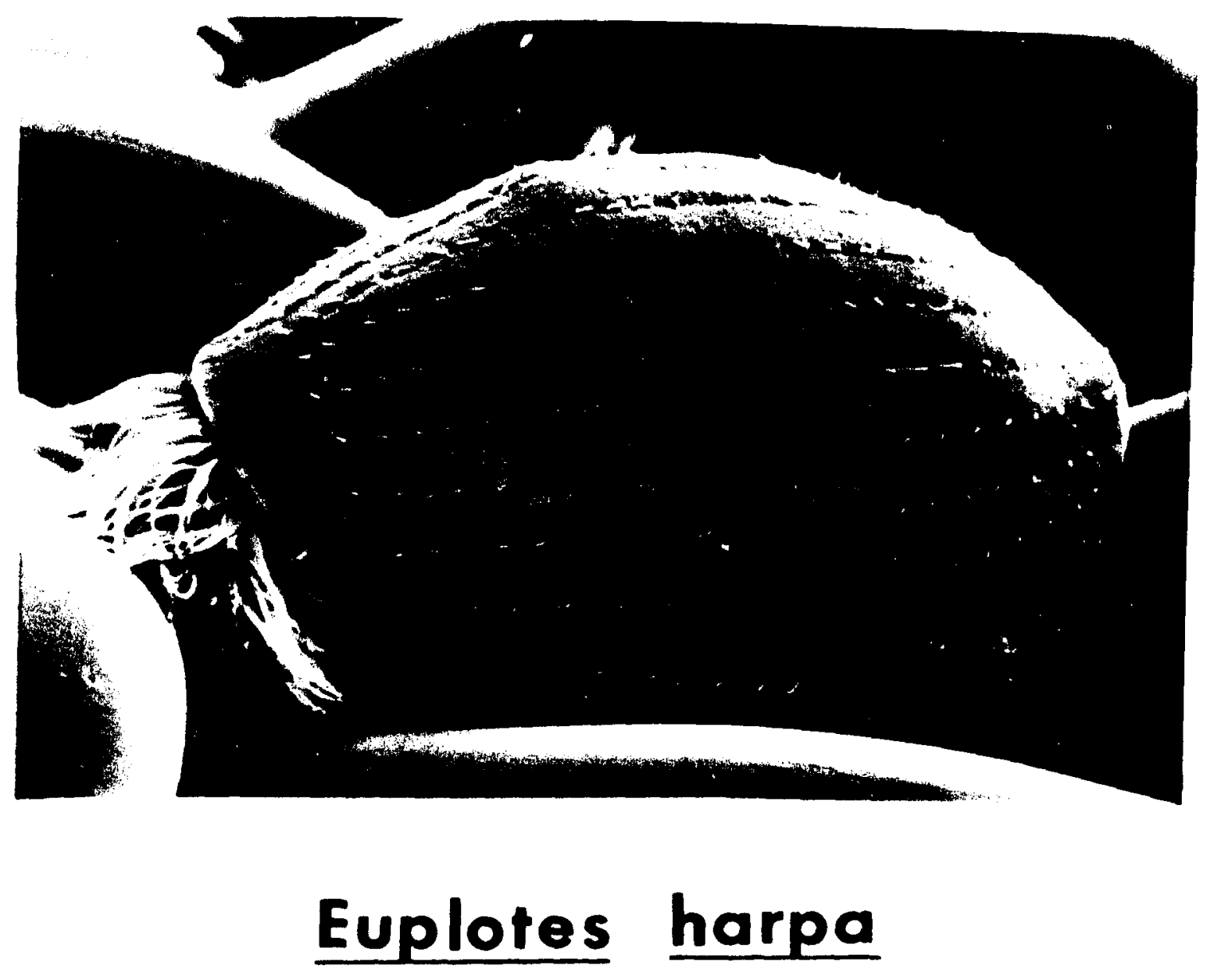

(Magnification: 950x) 
This thesis has been examined and approved.

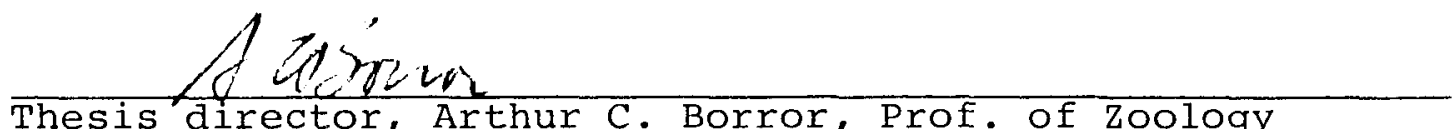

Thesis director, Arthur C. Borror, Prof. of Zoology

$$
\text { ac mothesen, }
$$

Arthur C. Mathieson, Prof. of Botany
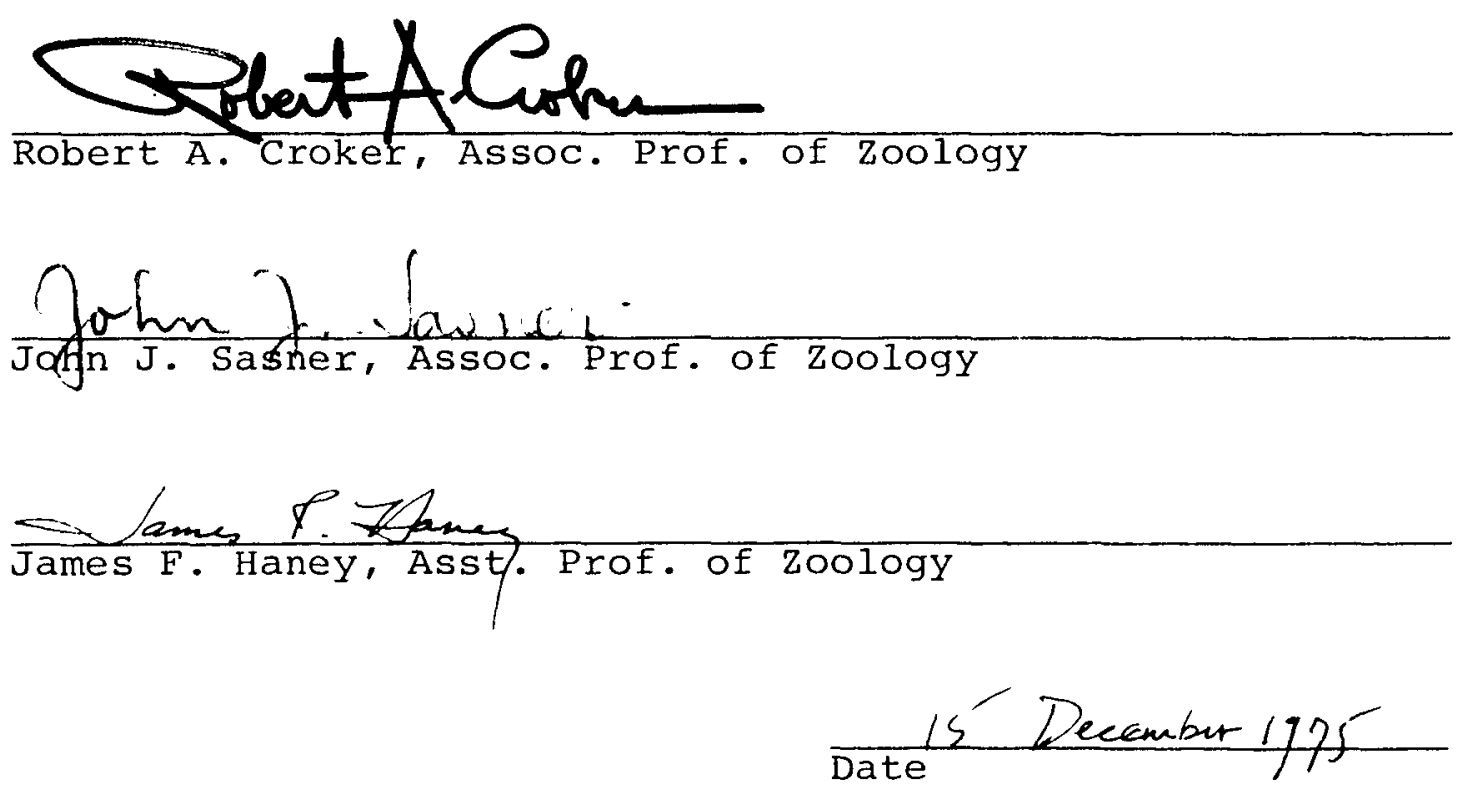
TO MY DAD

IN MEMORY OF HIS LOVE

AND DEVOTION

iii 


\section{ACKNOWLEDGEMENTS}

I extend my sincerest gratitude to my dissertation professor, Dr. Arthur C. Borror, for his assistance throughout the course of this investigation and for his guidance during my graduate tenure at the University of New Hampshire. My appreciation also to the members of my doctoral committee, Drs. Arthur C. Mathieson, Robert A. Croker, John J. Sasner and James F. Haney, for their advice during the course of this research. I am grateful to the AMR Corp., Burlington, Massachusetts and to Ms. Eleanor Tveter for the scanning electron microphotograph of Euplotes harpa. Special thanks are due to my family for their patience and understanding during the past several years while I pursued my graduate studies, and in particular to my wife, Luz, for typing and editing the manuscript.

Support provided by a University of New Hampshire Summer Fellowship for Teaching Assistants (1975) and research facilities at the Jackson Estuarine Laboratory, University of New Hampshire, is gratefully acknowledged. 
TABLE OF CONTENTS

LIST OF TABLES......................... vi

LIST OF FIGURES....................... vii

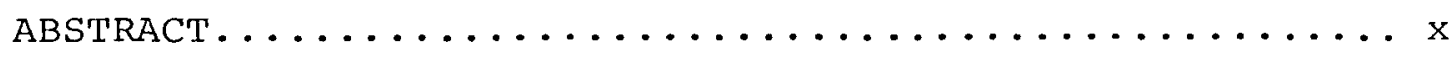

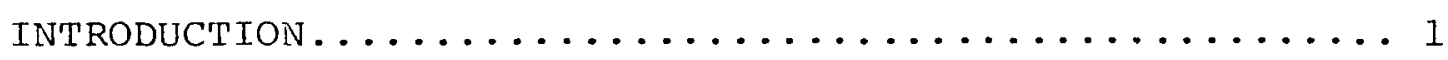

MATERIALS AND METHODS................... 8

General.......................... 8

Heating Apparatus...................... 18

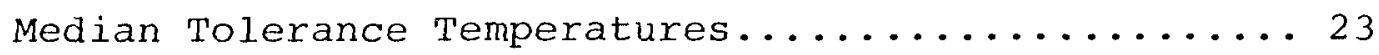

Growth Rates and Survival Limits.............. 24

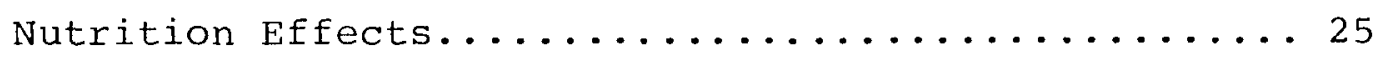

Competitive Interaction.................. 26

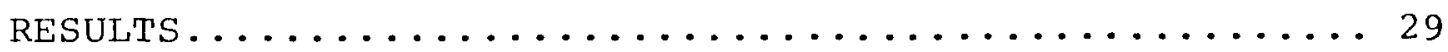

Heating Apparatus........................ 29

Growth Rates and Survival Limits.............. 29

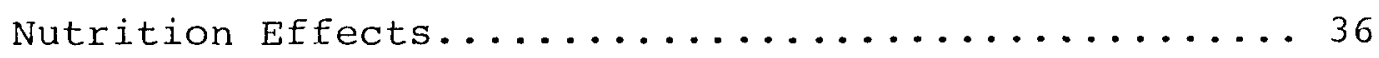

Salinity Effects..................... 36

Influence of Temperature on

Two-species Interaction................... 41

DISCUSSION............................ 71

IITERATURE CITED...................... 88 


\section{LIST OF TABLES}

1. Taxonomic Position and Cell Dimensions of Test Ciliates........................... 9

2. Antibiotic Mixture..................... 27

3. Comparison of Variability in Response to Acute Heat stress........................ 30

4. Temperature of Optimum Growth, Upper Thermal Limits of Significant Growth and Survival, and Tolerance to Acute Heat Stress $\left(L_{50}\right)$ for 12 Species of Ciliates.................... 35

5. Effect of Temperature and Salinity on the Generation Time (in Hours) of Three Species of Marine Ciliates...................... 39 
1. Dexiotricha $s p . \ldots \ldots \ldots \ldots \ldots \ldots \ldots \ldots \ldots \ldots \ldots \ldots \ldots$

2. Pleuronema coronatum Kent, $1881 \ldots \ldots \ldots \ldots \ldots \ldots 11$

3. Uronema marinum Dujardin, $1841 \ldots \ldots \ldots \ldots \ldots \ldots$ il

4. Strombidium sulcatum Claparède \& Lachmann, 1859.... 13

5. Tachysoma saltans (Cohn, 1866)............. 13

6. Trachelostyla pediculiformis (Cohn, 1866)....... 13

7. Euplotes alatus Kahl, $1932 \ldots \ldots \ldots \ldots \ldots \ldots \ldots \ldots$

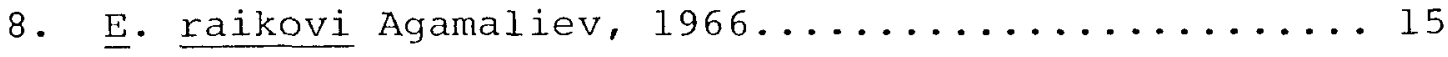

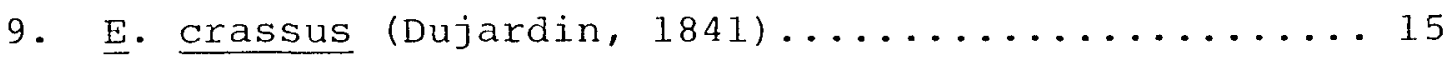

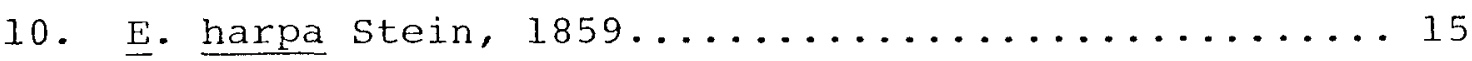

11. E. trisulcatus Kahl, $1932 \ldots \ldots \ldots \ldots \ldots \ldots \ldots \ldots \ldots$

12. Dexiotricha sp.......................... 17

13. Pleuronema coronatum................... 17

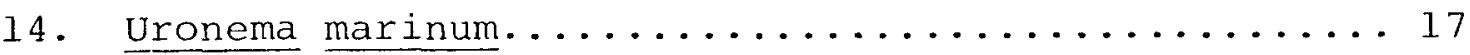

15. Strombidium sulcatum................... 17

16. Tachysoma saltans...................... 17

17. Trachelostyla pediculiformis................ 17

18. Euplotes alatus....................... 17

19. E. raikovi $\ldots \ldots \ldots \ldots \ldots \ldots \ldots \ldots \ldots \ldots \ldots \ldots \ldots \ldots \ldots \ldots \ldots$

20. E. trisulcatus $\ldots \ldots \ldots \ldots \ldots \ldots \ldots \ldots \ldots \ldots \ldots \ldots \ldots \ldots \ldots$

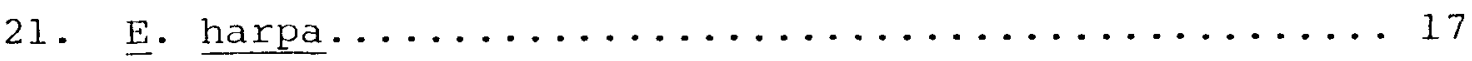

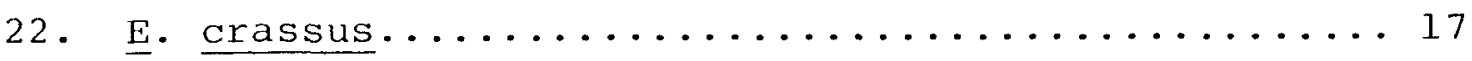

23. Condylostoma arenarium Spiegel, $1926 \ldots \ldots \ldots \ldots \ldots 17$

24. Heating apparatus attached to stereomicroscope.... 20

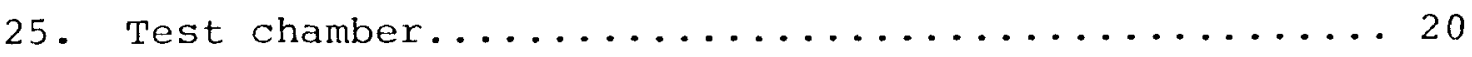


26. Heating rates of test solution when water bath is at $40^{\circ}, 45^{\circ}$ and $50^{\circ} \mathrm{C} \ldots \ldots \ldots \ldots \ldots \ldots \ldots \ldots \ldots \ldots \ldots \ldots$

27. Ranges of tolerance to acute heat stress........ 34

28. Rate of survival of Euplotes crassus at $37-38^{\circ} \mathrm{C}$ :

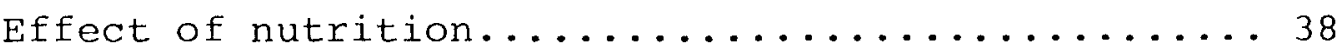

29. Effect of salinity on the heat resistance of Euplotes crassus cultivated at $10^{\circ} \mathrm{C} \ldots \ldots \ldots \ldots \ldots$

30. Effect of salinity on the heat resistance of Euplotes crassus cultivated at $15^{\circ} \mathrm{C} \ldots \ldots \ldots \ldots . \ldots 4$

31. Effect of salinity on the heat resistance of Euplotes crassus cultivated at $20^{\circ} \mathrm{C} \ldots \ldots \ldots \ldots \ldots 7$

32. Effect of salinity on the heat resistance of Euplotes crassus cultivated at $30^{\circ} \mathrm{C} \ldots \ldots \ldots \ldots . \ldots 49$

33. Influence of temperature and salinity on the heat resistance of Euplotes crassus........... 51

34. Generation time of seven species of ciliates at different temperatures................. 53

35. Interaction between Euplotes crassus and Strombidium sulcatum at $15^{\circ} \mathrm{C}$ and $0.001 \%$ proteose peptone and yeast extract........... 55

36. Interaction between Euplotes crassus and Strombidium sulcatum at $28^{\circ} \mathrm{C}$ and $0.001 \%$ proteose peptone and yeast extract........... 57

37. Interaction between Euplotes crassus and Strombidium sulcatum at $30^{\circ} \mathrm{C}$ and $0.001 \%$ proteose peptone and yeast extract............ 59 
38. Interaction between Euplotes crassus and Strombidium sulcatum at $15^{\circ}$ and $0.015 \%$

proteose peptone and yeast extract........... 62

39. Interaction between Euplotes crassus and

Strombidium sulcatum at $28^{\circ} \mathrm{C}$ and $0.015 \%$

proteose peptone and yeast extract............64

40. Interaction between Euplotes crassus and

E. harpa at $15^{\circ} \mathrm{C}$ and $0.001 \%$ proteose

peptone and yeast extract................ 67

41. Interaction between Euplotes crassus and

E. harpa at $28^{\circ} \mathrm{C}$ and $0.001 \%$ proteose

peptone and yeast extract.................. 69

42. Relationship between temperature of optimum

growth and temperature of $\mathrm{LD}_{50} \ldots \ldots \ldots \ldots \ldots \ldots$ 


\begin{abstract}
SENSTTIVITY OF MARINE CILIATES (PROTOZOA, CILIOPHORA) TO HIGH THERMAL STRESS
\end{abstract}

by

EDWIN A. MARTINEZ

The range of sensitivity of marine ciliates to temperatures near lethal maxima was determined under a variety of biotic and abiotic factors. Twelve species representing different taxa, sizes and modes of feeding and locomotion were examined. A simple heating apparatus consisting of a heated microscope stage was employed to subject the organisms to acute heat stress.

Ciliates are sensitive to elevated temperatures, especially when near their lethal limits. Heat resistance was influenced by cultivation temperature, salinity and nutrition. Temperatures of $\mathrm{LD}_{50}$ ranged from $31.5^{\circ} \mathrm{C}$ for Uronema marinum to $39.3^{\circ} \mathrm{C}$ for Dexiotricha $\mathrm{sp}$. When cultivated at low temperatures $\left(10^{\circ} \mathrm{C}\right)$, Euplotes crassus was more resistant to heat shock at higher salinities $(35$ o/oo) than at low salinities $(15 \mathrm{o} / 00)$. Thermal sensitivity depended also on acclimation temperature. Further, when cultured on a single species of bacteria, E. crassus was more sensitive to heat stress than when cultivated on an assortment of bacteria. The type of bacteria offered as food also determined its sensitivity to heat shock. 
Aside from accelerating the final outcome, a temperature increase from $15^{\circ}$ to $28^{\circ} \mathrm{C}$ had little influence on the competitive interaction between E. crassus and Strombidium sulcatum at the food levels tested $10.001 \%$ and $0.015 \%$ proteose peptone and yeast extract). At $30^{\circ} \mathrm{C}$, a temperature above the optimum for $\underline{E}$. crassus growth, the competitive effects of $\underline{E}$. crassus on $\underline{\text { S. }}$ sulcatum were further reduced. The data suggest that $\underline{E}$. crassus may have a competitive advantage over E. harpa at $15^{\circ}$, but not at $28^{\circ} \mathrm{C}$. It appears that the magnitude of a population is affected by the presence of other ciliates only when temperatures are below the optimum values of the interacting species. If temperature increases beyond these maxima, species interaction becomes negligible. 
INTRODUCTION

Over the past decade the increasing problem of thermal addition to aquatic environments resulting from power generation provided impetus for many studies concerned with the effects of chronic and acute heat stress on the physiology and ecology of many organisms. Among these are investigations not only on primary producers, but also on vertebrates, and many invertebrates. Major reviews of studies of heat stress include coutant (1969), Fry (1967), Kennedy \& Mihursky (1967), Krenkel \& Parker (1969) and McWhinnie (1967); also the Proceedings of the 2nd Thermal Workshop of the U.S. International Biological Program (1969) and Gibbons \& Sharitz (1974).

Estimates indicate that by 1980 one-third of the new and expanded power-generating installations requiring large volumes of water for their cooling systems will be located in estuarine and coastal areas (Anonymous, 1970; Clark \& Brownell, 1973; and Picton, 1960). For reasons outlined below, this study focuses on the effects of heat on marine Ciliophora.

Ciliated protozoa are shown to be important constituents of benthic communities of estuaries and of tidal marshes in particular (Borror, 1965, 1968, 1972, 1975; Brown, 1973; Fenchel, 1967, 1968a, b, 1969; Johannes, 1965; Kirby, 1934; and Webb, 1956), yet the literature reveals that they have received very little attention with regards to heat stress 
as an environmental factor.

Presently, little information is available on the exact trophic relationships of ciliates as prey for animals; however, their role as bacterivores and consumers of protophytes is well established. Several researchers (e.g., Burkholder, 1959; Fenchel, 1970; and Odum, 1970) have stated that ciliates comprise a definite link in the decomposer food chain system, while others believe that their major role lies in other equally important ecological functions. For example, according to Johannes (1965) ciliates maintain the bacterial concentration in a state of "prolonged physiological youth" by grazing and thus promote normal succession and recycling of nutrients (see also Bick, 1973 and references therein). Their numbers alone suggest that they exert a significant influence on the community. In fine sands and areas rich in bacterial growth, such as tidal marshes, ciliates range from $10^{6}$ to $4 \times 10^{7}$ individuals per $\mathrm{m}^{2}$ and are 10-100 times more numerous than the total number of metazoa (Fenchel, 1967). Their biomass $\left(0.03-2.3 \mathrm{~g}\right.$ wet $\left.\mathrm{wt} . / \mathrm{m}^{2}\right)$ is of the same order and often larger than the biomass of micrometazoa $\left(\sim 1.5 \mathrm{~g} / \mathrm{m}^{2}\right)$. Populations of ciliates inhabiting salt marshes are as rich and diverse as populations inhabiting sandy habitats of more open coasts (Borror, 1968). Further, ciliates may account for up to $25 \%$ or more of the total animal respiration of sublittoral sands (Fenchel, 1969); comparable estimates were established by Wieser \& Kanwisher (1961) in Spartina flats. Thus, they make a considerable contribution to the total 
energetics of these communities, and therefore information regarding their physiological tolerances is of concern to the complete understanding and protection of these "areas of critical environmental concern" (Clark \& Brownel1, 1973). The majority of previous research on thermal effects on ciliated protozoa is physiological or biochemical in scope. For example, the influence of temperature on nutrition and metabolism has received substantial emphasis (see reviews by Hall, 1967; Holz, 1964; and Hutner, 1961; also Reid et al., 1969; and Rosenbaum et al., 1966); the effects of certain salts and chemicals have been examined, and problems associated with physiological adaptation and mating types have attracted considerable attention (Crippa-Franceschi et a1. , 1973; CrippaFranceschi \& Genermont, 1973; Hairston \& Kellerman, 1965; Hipke \& Hanson, 1974; Holz et al., 1959; Hutchison, 1915; Kitching, 1948; Phelps, 1949; Poljansky, 1973; Poljansky \& Irlina, 1973; Poljansky \& Sukhanova, 1967; Propper, 1965; and Vogel, 1966). Other studies have shown that high temperatures can induce morphological alterations. These changes are manifested in heat impairment during stomatogenesis (e.g., Frankel, 1964) and on the overall size and general morphology of cells (James \& Read, 1957; Kiesselbach, 1935; Rosenbaum et a1., 1966; and Thormar, 1962a).

Generally, ciliates are cosmopolitan and temperature apparently plays a minor role in their ecology. However, several researchers have found that in some instances temperature is indeed significant in controlling the geographical 
distribution and occurrence of ciliates. For example, the freshwater ciliate Neobursaridium gigas occurs only in tropical regions and reproduces only at temperatures between $22^{\circ}$ and $26^{\circ} \mathrm{C}$ (Dragesco, 1968). Euplotes antarcticus, recently described from Antarctic sea ice by Lee \& Fenchel (1972), survives only in temperatures below $17^{\circ} \mathrm{C}$ and reproduces only between $-2^{\circ}$ and $10^{\circ} \mathrm{C}$, the optimum being approximately $5^{\circ} \mathrm{C}$. Dingfelder (1962) also showed that, among other Protozoa, certain ciliates can tolerate high temperatures of temporary shallow freshwater pudales. For the most part, however, the research cited above was conducted mainly on freshwater species of Paramecium, Tetrahymena or Colpidium; only the studies of Fenchel (1968b), Kiesselbach (1935), Lee \& Fenchel (1972) and Vogel (1966) dealt with marine ciliates. Of the investigations concerned with effects of high temperatures resulting from or related to man induced environmental changes, only those of Lee et al. (1971) and Saks et al. (1974) consider, among other salt marsh organisms, the impact of high temperatures on a marine ciliate (Euplotes vannus). Cairns (1969a, b) demonstrated changes in species diversity and in stability of freshwater protozoan communities as a consequence of high thermal shock. Hence, for both basic and practical reasons, a major thrust of the present study was to survey the ranges of sensitivity to high temperatures on selected representatives of marine Ciliophora. In comparative studies the median tolerance limit (LD50) or median tolerance temperature has been used to define the physiological tolerance of organisms under stressful 
experimental situations (Kinne, 1963, 1964, 1967; and Vernberg \& Vernberg, 1970). One objective of this study, therefore, was to determine the LD50 of several species of ciliates. To achieve this, a simple heating apparatus was designed and constructed so that organisms could be subjected to abrupt increases in temperature while simultaneously allowing observation of the cells (see Materials and Methods). Salinity and temperature behave synergistically to influence the response of organisms to thermal changes (Kinne, 1964; McLeese, 1956; and Vernberg \& Vernberg, 1974). Since both of these ecological parameters are important in tidal marshes, another aim was to examine the effects of acclimation temperature and salinity on ciliate responses to high thermal stress. Nutrition, a factor that may influence resistance to heat stress, also was investigated.

Since so many variables are involved, optimum conditions are difficult to define even in the laboratory; indeed, in the field optimum conditions may never be realized. Nevertheless, the laboratory situation enables us to control variables and thus treat experimental organisms in such a manner whereby a standard optimum state may be achieved. Optima are especially useful as points of reference; i.e., they not only enable one to make comparisons between species, but also allow better comprehension of a particular organism's tolerance limits. Therefore, another goal was to determine the temperature of optimum growth for each ciliate. According to Clark \& Brownell (1973) Atomic Energy Commission calculations show that if all power plants under 
construction or in operation in the Hudson estuary were cooled with once-through systems, the temperature of a 35-mile stretch of the estuary would be raised by $5-6^{\circ} \mathrm{C}$. Such increases above ambient are even more crucial during summer when estuarine organisms may already be living near their upper thermal limits. Therefore, while exposure to abrupt increases in temperature may certainly be lethal, prolonged exposure to sublethal temperatures may be even more significant. Thus, experiments were conducted to evaluate the upper thermal limits for significant growth and survival.

Under natural conditions, increasing temperatures may modify competitive interaction. This may be displayed in the exclusion of the more sensitive species, or conversely in the enhancement of particular species at the expense of others as they are favored by elevated temperatures. Freshwater algae, for instance, have been shown to exhibit this phenomenon as have other components of marine aufwuchs communities (Cairns, 1956; Saks et a1., 1974). To test the extent or occurrence of this principle, I chose strombidium sulcatum, a planktonic form, and Euplotes crassus, a benthic ciliate for competitive interaction experiments at different temperatures. Both are ubiquitous marine ciliates with similar growth rates at extreme temperatures (see Results). Sublethal increases in temperature may favor one ciliate at the expense of another, even if environmental temperatures do not reach lethal levels. This may be significant in terms of ecosystem succession and fouling phenomena. Competitive interaction is usually more severe among 
closely related species and when a common resource such as food is exploited by similar means. For these reasons I have studied the interaction between E. crassus and E. harpa at extreme temperatures; both are benthic and feed by grazing along the substrate.

In summary, this research documents the ranges of sensitivity to high temperatures on selected representatives of marine ciliates. Temperature optima, upper thermal limits of significant growth and survival, and temperatures of $\mathrm{LD}_{50}$ were determined for twelve species. The effects of nutrition and the influence of temperature and salinity on ciliate responses to acute heat stress were also tested. Finally, the influence of increasing temperature and food concentration on competitive interaction was examined. 
MATERIALS AND METHODS

Twelve species of marine ciliates were isolated from mass and raw cultures of collections made in the spring of 1973 and 1974, and the summer and fall of 1974. They were collected from New Hampshire tidal marshes at odiorne Point, Rye $\left(43^{\circ} 2^{\prime} 22^{\prime \prime} \mathrm{N} ; 70^{\circ} 42^{\prime} 57^{\prime \prime} \mathrm{W}\right)$ and Adams Point, Durham $\left(43^{\circ} 5^{\prime} 22^{\prime \prime} \mathrm{N} ; 70^{\circ} 52^{\prime} 15^{\prime \prime} \mathrm{W}\right)$. One species, Euplotes alatus, was collected at mid tide level of a sandy habitat at Rye Beach, New Hampshire $\left(43^{\circ} 00^{\prime} 40^{\prime \prime} \mathrm{N} ; 70^{\circ} 44^{\prime} \mathrm{I}^{\prime \prime} \mathrm{W}\right)$. Several taxonomic and morphologic groups are represented as well as different modes of feeding and locomotion; i.e., benthic and planktonic, and include the largest and smallest forms (Table 1). To show the basic morphological characters of the ciliates and to demonstrate their relative proportions, illustrations drawn to scale are presented in Figures 1-23. Identifications were made with living ciliates and with ciliates prepared for cortical staining according to a modification of the NMF (Nigrosin- $\mathrm{HgCl}_{2}$-Formalin) method (Borror, personal communication), the Chatton-Lwoff silver impregnation technique as modified by Corliss (1953), Feulgen nucleal reaction, and iron hematoxylin. The smaller species were extracted from salt marsh sediments, algae, or detritus by filtration through a series of filters fitted with nylon gauze of mesh sizes ranging from 1050 to $64 \mu \mathrm{m}$ and from marine sand by the seawater-ice method (Uhlig, (1964) . 
Table 1. TAXONOMIC POSITION AND CELL DIMENSIONS OF TEST CILIATES

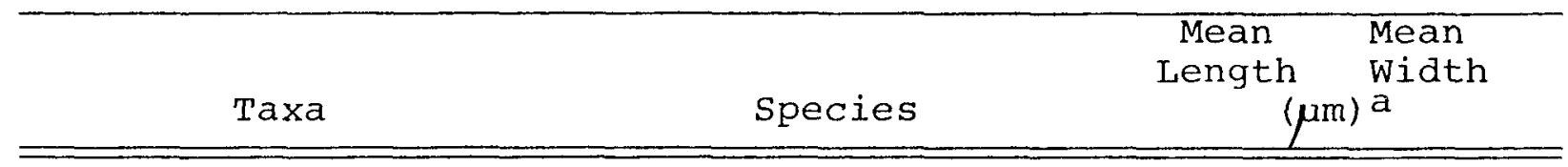

Phylum Ciliophora

Class Oligohymenophora

Subclass Hymenostomata

Order Scuticociliatida

Family Loxocephalidae

Dexiotricha sp. $\quad 78.4 \quad 25.1$

Family Pleuronematidae

Pleuronema coronatum

78.9

43.8

Family Uronematidae

Uronema marinum $\quad 30.8 \quad 13.4$

Class Polyhymenophora

Subclass Spirotricha

Order Heterotrichida

Family Condylostomatidae

$\frac{\text { Condylostoma }}{\text { arenarium }}$

353.3

96.1

Order Oligotrichida

Family strombidiidae

$\underline{\text { Strombidium }}$ sulcatum

40.6

30.2

Order Hypotrichida

Family oxytrichidae

$\frac{\text { Tachysoma }}{\text { saltans }}$

48.0

25.3

Trachelostyla pediculiformis

$143.9 \quad 26.8$

Family Euplotidae

Euplotes alatus $\quad 41.0 \quad 26.2$

E. crassus $\quad 91.4 \quad 57.8$

E. harpa $\quad 145.8 \quad 86.9$

E. raikovi $\quad 45.2 \quad 30.2$

E. trisulcatus $\quad 55.2 \quad 36.2$

$\mathrm{a}_{\mathrm{Ce}} 1 \mathrm{l}$ dimensions of 10 individuals at $20^{\circ} \mathrm{C}$ and $25 \mathrm{o} / 00 \mathrm{~S}$ 
Figures $1-3$.

1. Dexiotricha sp.

2. Pleuronema coronatum Kent, 1881

3. Uronema marinum Dujardin, 1841 


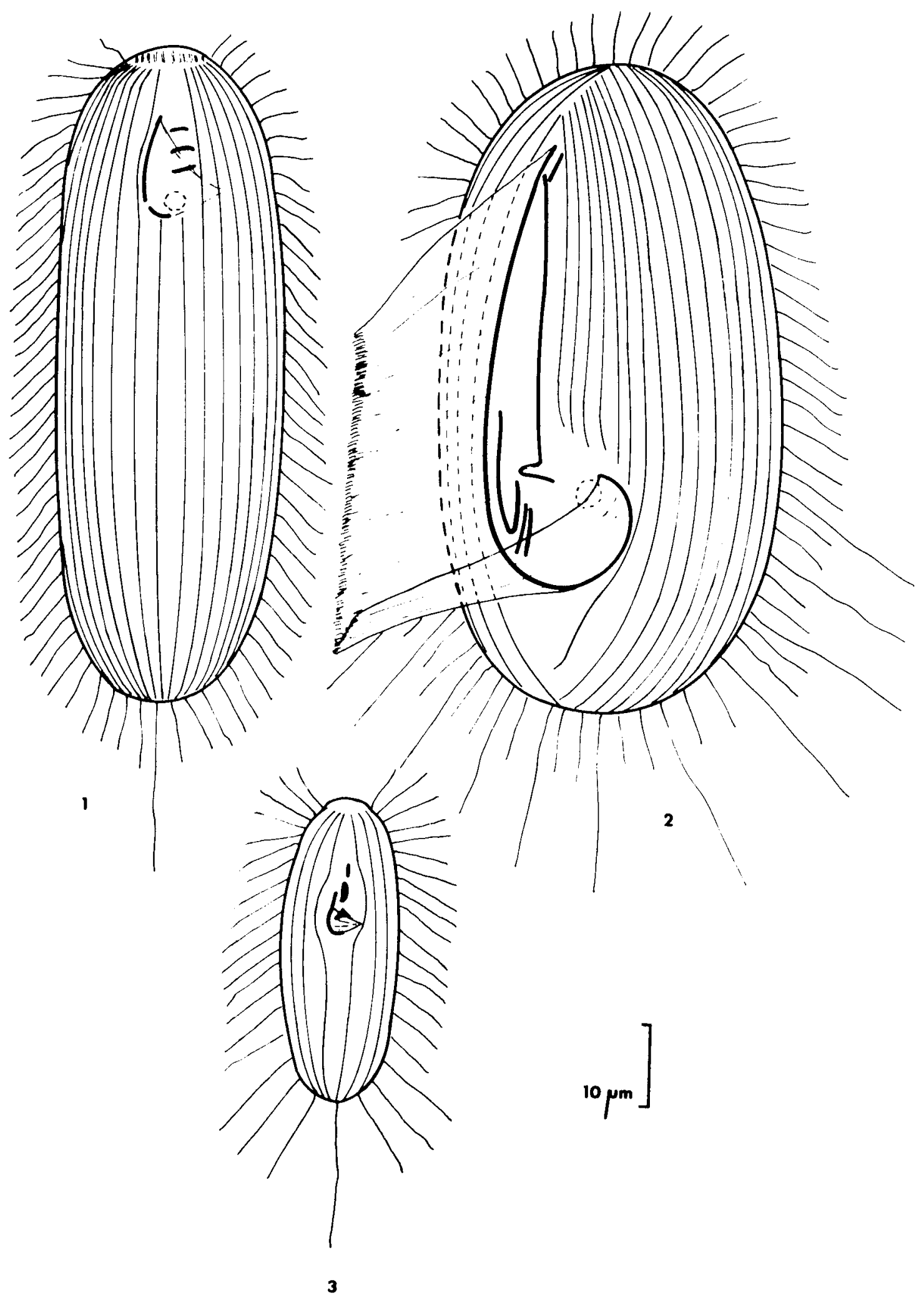


Figures 4-6.

4. Strombidium sulcatum Claparède \& Lachmann, 1859

5. Tachysoma saltans (Cohn, 1866)

6. Trachelostyla pediduliformis (Cohn, 1866) 

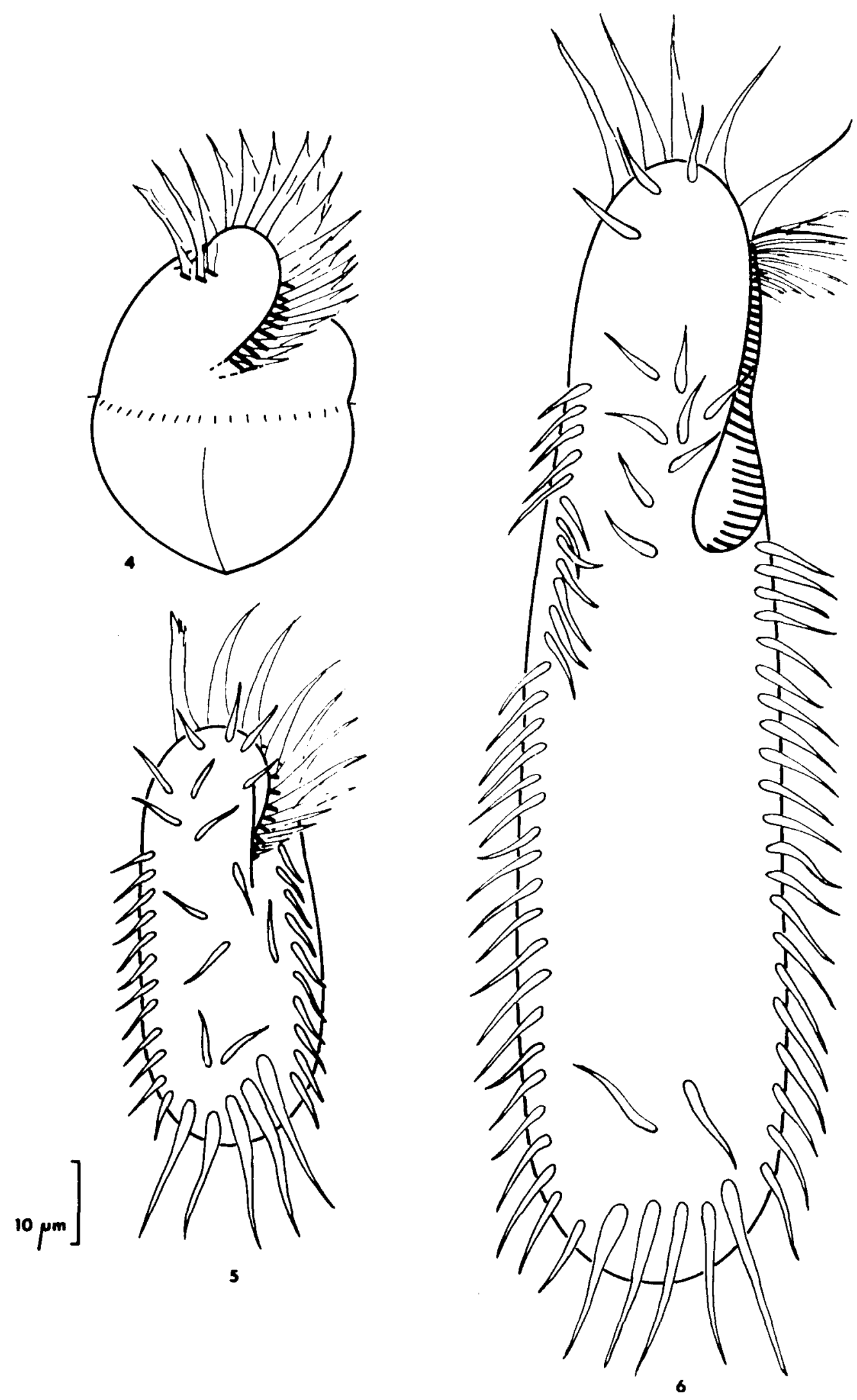
Figures 7-11.

7. Euplotes alatus Kahl, 1932

8. E. raikovi Agamaliev, 1966

9. E. crassus (Dujardin, 1841)

10. E. harpa Stein, 1859

11. E. trisulcatus Kahl, 1932 


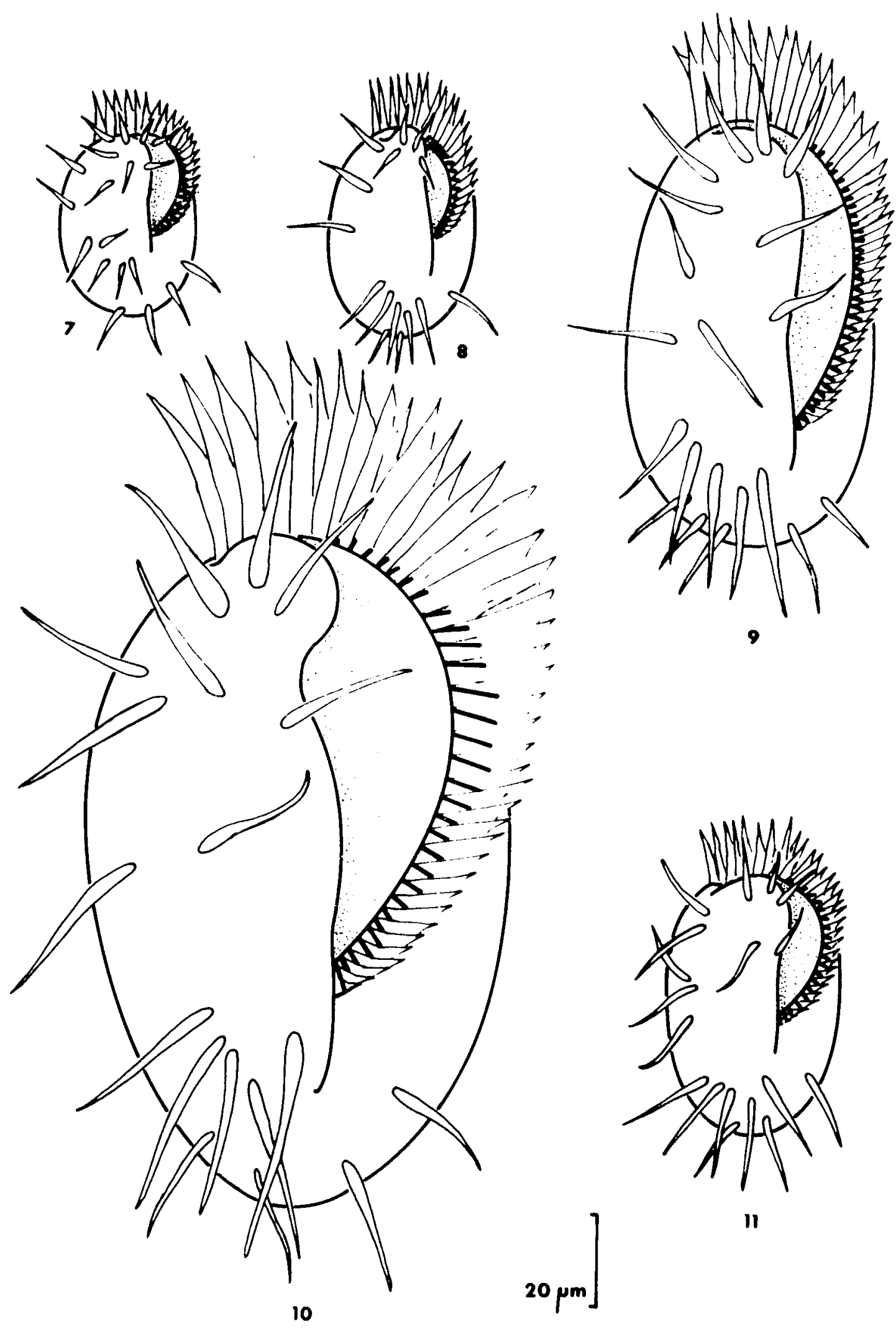


Figures 12-23.

12. Dexiotricha sp.

13. Pleuronema coronatum

14. Uronema marinum

15. Strombidium sulcatum

16. Tachysoma saltans

17. Trachelostyla pediculiformis

18. Euplotes alatus

19. E. raikovi

20. E. trisulcatus

21. E. harpa

22. E. crassus

23. Condylostoma arenarium Spiegel, 1926 


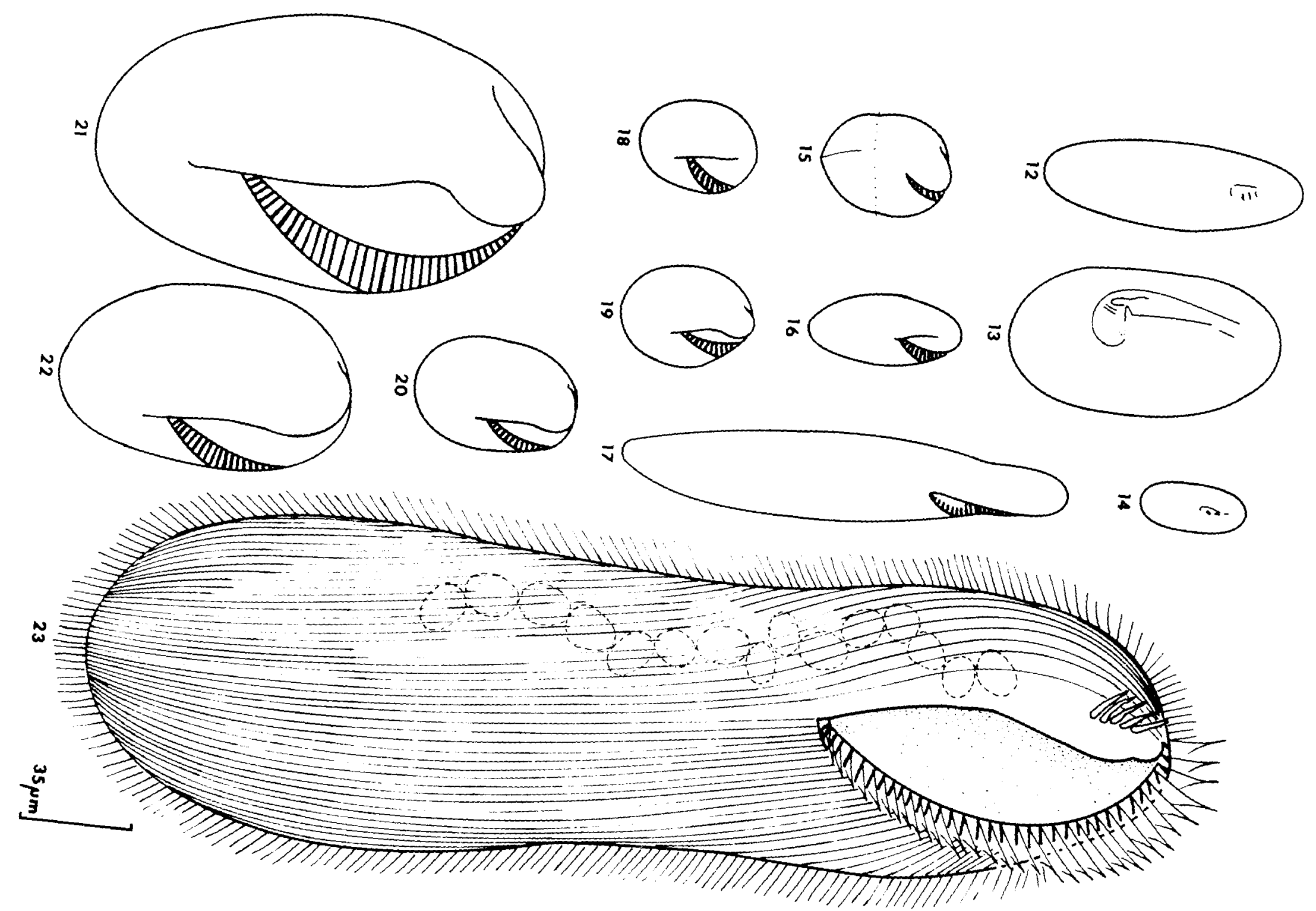


Clone cultures of isolated ciliates were maintained at $20^{\circ} \mathrm{C}$ in $100 \mathrm{ml}$ seawater (25 o/oo S) contained in $250 \mathrm{ml}$ capacity Erlenmeyer flasks. As a nutrient, either rice grains or a 4:1 mixture of proteose peptone and yeast extract (PPY) was added to seawater. Depending upon experimental requirements, concentrations of PPY ranged Erom 0.001-0.015\%. Salinity and temperature were varied according to experimental design, and $\mathrm{pH}$ typically was $7.8-7.9$.

HEATING APPARATUS. A resistance heater epoxyed to the bottom of a glass stage of a dissecting stereomicroscope allowed administration of acute heat stress (Fig. 24). The flow of current through the heating element was regulated with a transformer and a Variac rheostat.

The test chamber was the center well of 3 -hole spot plates made of clear glass, and of $1 \mathrm{ml}$ capacity (Fig. 25). Two thermistor probes, one on either side of the test chamber, monitored the temperature of the water bath. To determine heating rates of the test solutions, I fitted another thermistor probe into one of the test chambers by filing a groove on the surface of the spot plate thus accommodating the wire leads of the thermistor probe $(2 \times 13 \mathrm{~mm})$. The wire leads were then epoxyed into the groove, flush with the surface of the chamber which was then closed with a cover slip during heating rate determinations. All thermistor probes were connected through a switch box to a temperature indicator (Atkins Technical, Inc., Model 3HOI-Cl0).

Figure 26 illustrates the heating characteristics of 
19

Figure 24. Heating apparatus attached to stereomicroscope.

Figure 25. Test chamber 


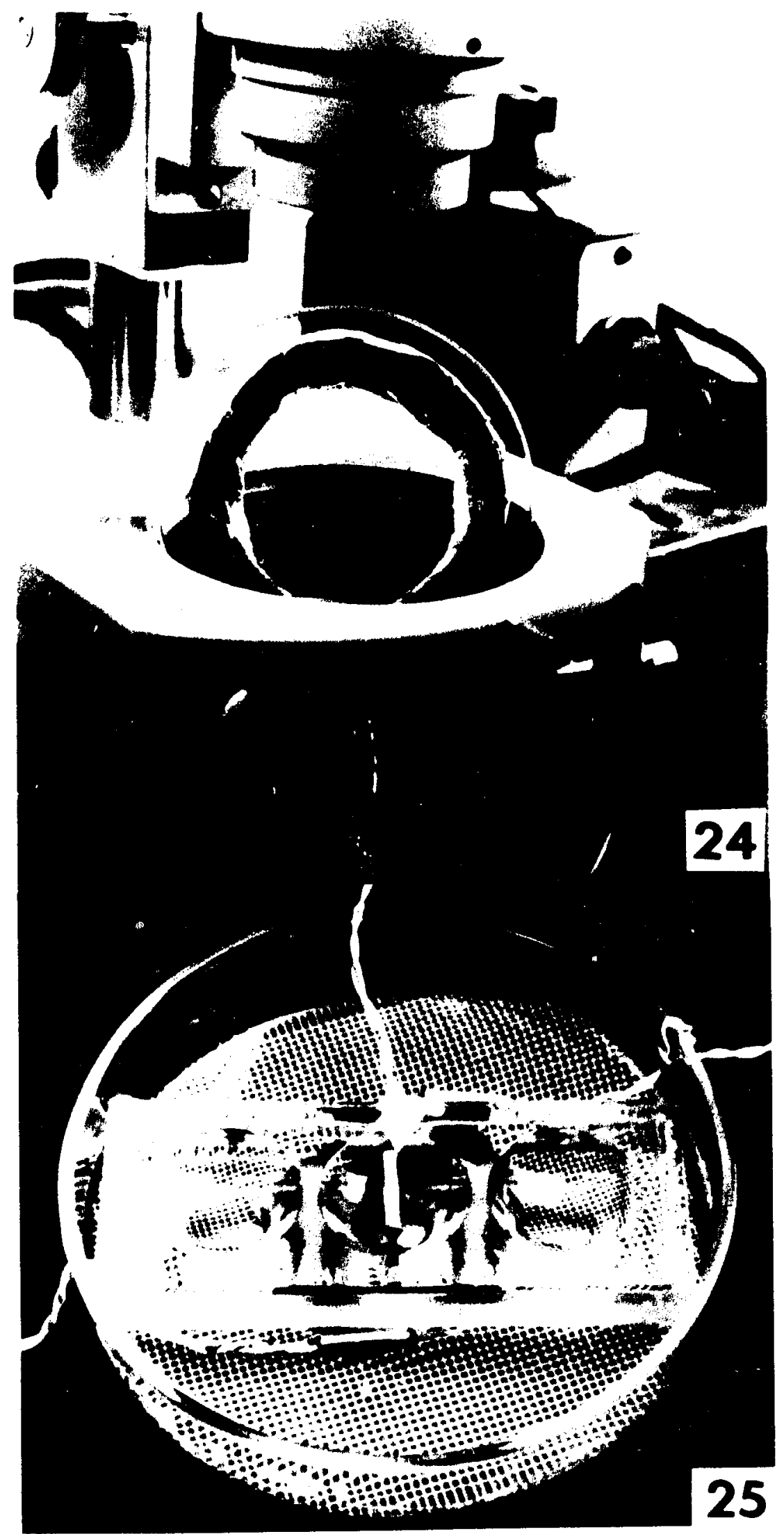


Figure 26. Heating rates of test solution when water bath is at $40^{\circ}, 45^{\circ}$ and $50^{\circ} \mathrm{C}$. Each point represents the mean of 10 replicates. Vertical lines about the means are standard deviations. 


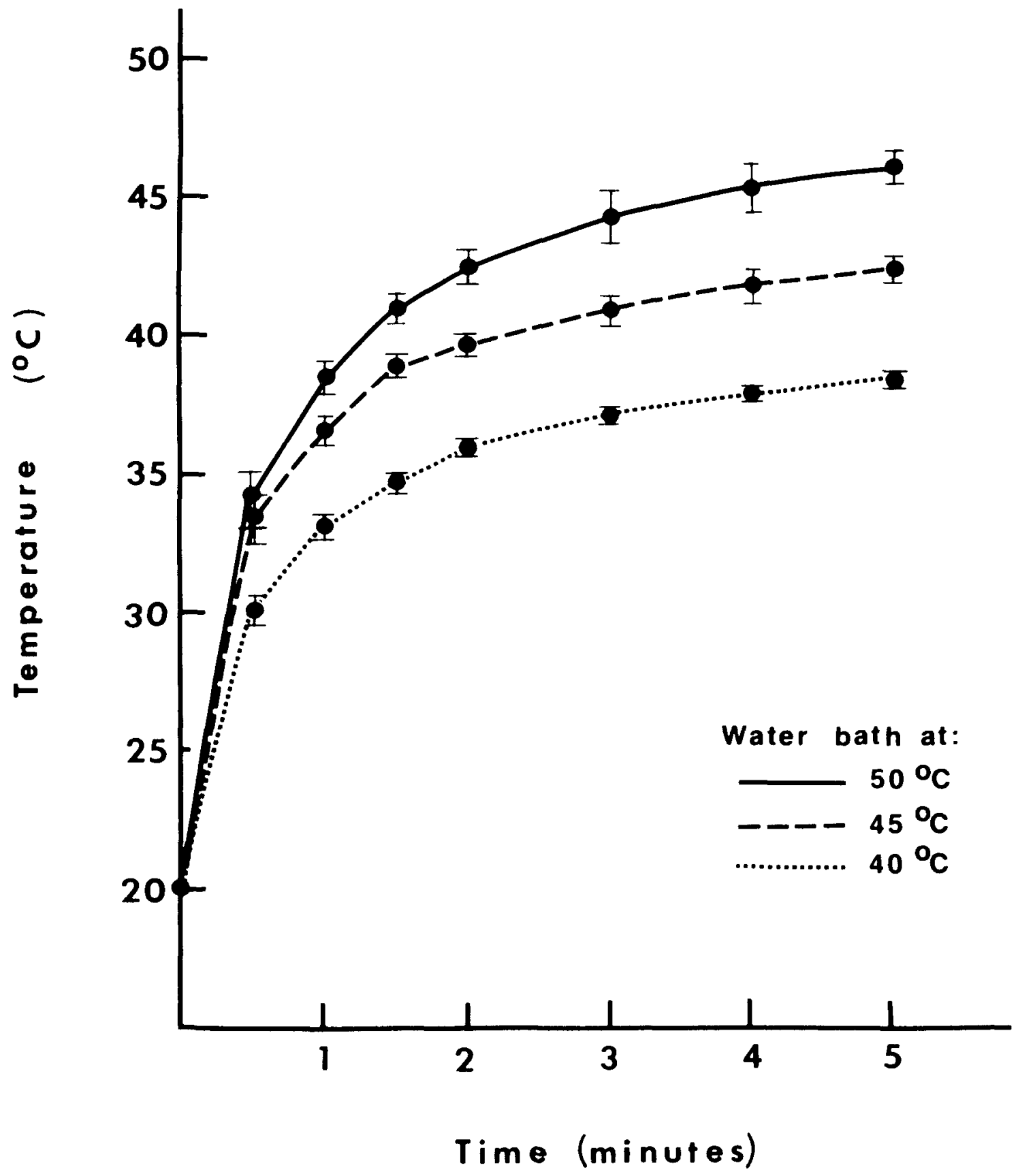


the test chambers when the water bath temperature was held constant at $40^{\circ}, 45^{\circ}$ and $50^{\circ} \mathrm{C}$. These water bath temperatures permitted a selection of test temperatures that could be administered rapidly with minimum time variation. Variability between replicates was sufficiently small such that at any instant the temperature of the test solution could be predicted accurately so long as the temperature of the water bath was maintained constant. With establishment of the heating characteristics of the test chamber, many spot plates of similar design and dimensions could be used successively during actual determinations of lethal thermal limits.

MEDIAN TOLERANCE TEMPERATURES. Since one objective was to determine the median tolerance temperature $\left(\mathrm{LD}_{50}\right)$ of each species, ciliates were subjected to acute heat stress with the apparatus described above. Heating rates were selected so that all $L_{50}$ 's were attained within approximately 60 seconds. This minimized variability of the time factor between species while subjecting them to an abrupt increase in temperature as rapidly as possible. In a typical experiment, a known number of ciliates (average: 30-40) contained in $1 \mathrm{ml}$ of fresh culture fluid (seawater of salinity comparable tc that of original culture) was introduced into a preheated test chamber and sealed with a cover slip. After heating to the desired temperature for a predetermined period (e.g., 45, 60 or 75 seconds), the test chamber was removed from the hot water bath and immediately transferred (within 3 seconds) to a cold one $\left(5-8^{\circ} \mathrm{C}\right)$ in a refrigerator. This 
effectively stopped further heating of the organisms. For example, when heated to $34.5^{\circ}$ and to $39.9^{\circ} \mathrm{C}$, the temperature of the test solution begins to drop after 10 seconds in a cold water bath of $8^{\circ} \mathrm{C}$. By the end of three minutes the temperature drops to $25-26^{\circ} \mathrm{C}$ and to $26.6^{\circ} \mathrm{C}$, respectively. Test cells were harvested from cultures in log growth, a condition determined from previous observations on growth rates, vigor and general condition of the cells and of the culture as a whole. At least three, but usually five to six replicates were conducted at each temperature. After heat treatment and subsequent cooling, the ciliates were maintained at room temperature $\left(20-23^{\circ} \mathrm{C}\right)$ for $30-60$ minutes prior to determination of mortality rates to allow for recovery from temperature shock. With the exception of actual heating, controls received similar treatment. Death was defined as the point at which the ciliates ceased motility. Additional comments and observations on mortality will be discussed later.

GROWTH RATES AND SURVIVAL LIMITS. TO determine upper thermal limits of significant growth (generation time within 72 hours) and temperature of optimum growth (maximum growth rate) for each species, cultures were initiated with 2-10 individuals in $1 \mathrm{ml}$ of 25 o/oo $\mathrm{S}$ seawater at temperatures between $20^{\circ}$ and $38^{\circ} \mathrm{C}(2-5$ replicates at each temperature). Growth rates were estimated after 3-10 days by total cell counts; these provide reasonable estimates of the mean generation time (Fenchel, 1968b). The ciliates were counted under a 
dissecting microscope by removing them with a pipette from an evaporating dish. Rates of growth for Uronema marinum were obtained with $0.05 \mathrm{ml}$ cultures initiated with $1-2$ cells, and were checked with greater frequency. Upper thermal limits of survival were obtained when cultures either exhibited just slight growth or when at least $75 \%$ of the original number of cells remained after exposure to experimental temperatures for up to 72 hours. To examine the influence of salinitytemperature interaction on reproductive rates, Dexiotricha sp. was grown at $15^{\circ}$ and $30^{\circ} \mathrm{C}$, Euplotes crassus and strombidium sulcatum at $10^{\circ}, 20^{\circ}$ and $30^{\circ} \mathrm{C} ;$ and all three at salinities of 15, 25 and 35 \%/00. These three species represent not only different taxa, planktonic and benthic forms, but also exhibit wide ranges of thermal tolerance thus making them appropriate candidates for this experiment.

NUTRITION EFFECTS. To determine the effects of nutrition on the heat sensitivities of ciliates, I cultivated Euplotes crassus on monobacterial cultures of Arthrobacter marinus and

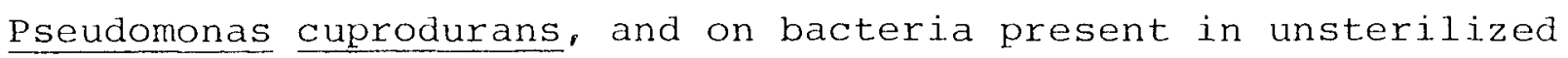
seawater. Pure strains of $\underline{A}$. marinus and $\underline{P}$. cuprodurans were maintained on nutrient agar slants (medium 2216E, ZoBell, 1941) at $4^{\circ} \mathrm{C}$. Millipore Eiltered $(0.22 \mu \mathrm{m})$ seawater was enriched with sterile PPY $(0.01 \%)$ and aliquots, each of $100 \mathrm{ml}$ contained in $250 \mathrm{ml}$ capacity Erlenmeyer flasks, were inoculated with either A. marinus or $\underline{P}$. cuprodurans and incubated at $20^{\circ} \mathrm{C}$ for 24 hours. The inocula were transferred directly from the agar slants with an inoculating loop. The purity of these monobacterial cultures 
was confirmed by inoculating $0.01 \mathrm{ml}$ samples on nutrient agar plates. Unfiltered seawater enriched with PPY was also incubated at $20^{\circ} \mathrm{C}$ for 24 hours. Although no attempt was made at identification of the bacteria present in the unfiltered seawater, this assortment provided a suitable substrate for culturing E. crassus.

Before introducing $\underline{E}$. crassus into the bacterized seawater, the ciliates were serially washed in two baths of sterile seawater for 15-20 minutes each, then transferred through three baths of an antibiotic mix (Table 2, modified from Lee et a1., 1970) for 15, 30 and 60 minute durations. A 15 minute wash in sterile seawater concluded the series. Except for the unfiltered seawater cultures, all techniques were aseptic.

Cells were harvested during $\log$ growth and tested for resistance to heat by introducing them with a small volume $(\sim 0.5 \mathrm{ml})$ of culture fluid into $37-38^{\circ} \mathrm{C}$ seawater. After $0.5,1,2,3,4,5$ and 6 minutes the dish containing the ciliates was removed from the heat source (Precision oven) to a cold water bath, and then to room temperature before determination of survival rates. At least four replicates were conducted for each period of heat treatment. COMPETITIVE INTERACTION. TO ascertain whether or not the outcome of competitive interaction is affected by temperature, I cultured Euplotes crassus and Strombidium sulcatum first as isolates then in mixed cultures at $15^{\circ}$, $28^{\circ}$ and $30^{\circ} \mathrm{C}$. The similarity in their temperature growth 
Table 2. ANTIBIOTIC MIXTURE

Constituents ${ }^{\mathrm{a}} \quad \mu \mathrm{g} / 100 \mathrm{m1}$

\begin{tabular}{lc}
\hline \hline Albamycin & 200 \\
Chloromycetin & 250 \\
Streptomycin sulfate & 2000 \\
Fungizone & 50 \\
\hline Albamycin (Sodium novobiocin), Mix-o-Vial, The \\
Upjohn Co.; Chloromycetin (Chloramphenicol), Parke, \\
Davis \& Co.; Streptomycin sulfate, Eli Lilly \& Co.; \\
Fungizone (Amphotericin B), E. R. Squibb \& Sons, Inc.
\end{tabular}


requirements makes them suitable candidates for this experiment. Al1 cultures were inoculated with 10 individuals of each species and a ratio of 1:1 was retained in the inocula of the paired species, thus eliminating any initial numerical advantage. Since competitive interaction may be enhanced not only by temperature changes but also by availability of food, two levels of food concentration were offered at the $15^{\circ}$ and $28^{\circ} \mathrm{C}$ experiments. Seawater $(250 / 00 \mathrm{~S})$ enriched with $0.001 \%$ PPY constituted a low food supply and seawater with $0.015 \%$ PPY was arbitrarily established as the higher food level. The experiment was repeated with two closely related species, Euplotes crassus and E. Harpa, at $15^{\circ}$ and $28^{\circ} \mathrm{C}$.

Cultures were $1 \mathrm{ml}$ in volume and contained in sealable vials (Wheaton snap cap bottles, $4 \mathrm{ml}$ capacity; Carolina Biological Supply Co.). The mean number of ciliates of triplicate cultures was determined by direct cell counts following the technique described above (see pp. 24-25). Statistical methods are according to Sokal \& Rohlf (1969) and Yo'ing \& Veldman (1972). 


\section{RESULTS}

HEATING APPARATUS. Table 3 provides a comparison of the response of ciliates to acute heat stress administered with the heating apparatus. In all but three cases, namely Dexiotricha sp., Strombidium sulcatum and Euplotes harpa cultured at $20^{\circ} \mathrm{C}$ and $25 \% / 00 \mathrm{~S}$, variability in mortality rates decreased with increasing test temperatures. The coefficient of variation (CV) for Condylostoma arenarium, for example, diminished from 93\% to $0 \%$ as these ciliates were subjected to temperatures ranging from $37^{\circ}$ to $40.9^{\circ} \mathrm{C}$. Greater uniformity in response was therefore obtained as shock temperatures were increased. Although care was taken to minimize variability in the manner in which replicates were conducted both within a particular species and between different species, it is possible that along with the natural variation inherent in the response of biological systems to a stimulus, small thermal gradients in the test chamber may also have contributed to the total variability in mortality rates. However, the heating apparatus provides reasonably good estimates of median tolerance temperatures, especially since these are so close to the LD 100 limits, often less than $1^{\circ} \mathrm{C}$ (see Fig. 27).

GROWTH RATES AND SURVIVAL LIMITS. In addition to temperatures of $\mathrm{LD}_{50}$, Table 4 also shows temperatures of optimum growth, and upper thermal limits of significant growth and survival for all the ciliates studied. Temperatures 
Table 3. COMPARISON OF VARIABILITY IN RESPONSE TO ACUTE HEAT STRESS

\begin{tabular}{|c|c|c|c|c|c|}
\hline $\begin{array}{l}\text { Organism } \\
\text { (Culture } \\
\text { conditions) }\end{array}$ & $\begin{array}{l}\text { Test } \\
\text { temp. } \\
\left({ }^{\circ} \mathrm{C}\right)\end{array}$ & $\mathrm{N}$ & $\begin{array}{l}\# \text { cells } \\
\text { per } N\end{array}$ & $\begin{array}{l}\text { \% Mortality } \\
\text { Mean } \pm \text { S.E. }\end{array}$ & $\mathrm{CV}^{\mathrm{a}}$ \\
\hline \multirow{4}{*}{$\frac{\text { Condylostoma }}{\frac{\text { arenarium }}{\left(20^{\circ}, 250 / 00\right)}}$} & 37.0 & 4 & $26-30$ & $10.7 \pm 5.00$ & 93.0 \\
\hline & 38.4 & 8 & $24-34$ & $38.8 \pm 7.25$ & 52.0 \\
\hline & 39.9 & 5 & $27-32$ & $69.5 \pm 5.11$ & 16.7 \\
\hline & 40.9 & 3 & $15-28$ & $100.0 \pm 0.00$ & 0.0 \\
\hline Dexiotricha sp. & 36.5 & 3 & $34-36$ & $9.2 \pm 6.75$ & 60.8 \\
\hline \multirow[t]{3}{*}{$\left(20^{\circ}, 250 / 00\right)$} & 38.4 & 4 & $35-40$ & $36.5 \pm 1.18$ & 64.6 \\
\hline & 39.9 & 4 & 40 & $60.0 \pm 10.02$ & 33.8 \\
\hline & 40.9 & 5 & $20-40$ & $100.0 \pm 0.00$ & 0.0 \\
\hline \multirow{4}{*}{$\begin{array}{l}\frac{\text { Pleuronema }}{\text { coronatum }} \\
\left(20^{\circ}, 25 \mathrm{o} / 00\right)\end{array}$} & 32.0 & 5 & $25-33$ & $17.8 \pm 3.39$ & 42.7 \\
\hline & 34.6 & 12 & $26-38$ & $22.0 \pm 1.64$ & 25.6 \\
\hline & 36.5 & 3 & 40 & $40.0 \pm 2.40$ & 10.5 \\
\hline & 37.0 & 4 & $30-40$ & $100.0 \pm 0.00$ & 0.0 \\
\hline \multirow{3}{*}{$\frac{\frac{\text { Strombidium }}{\text { sulcatum }}}{\left(20^{\circ}, 25 \mathrm{o} / 00\right)}$} & 34.6 & 5 & $44-62$ & $33.8 \pm 2.72$ & 18.0 \\
\hline & 36.5 & 5 & $52-60$ & $51.0 \pm 5.82$ & 25.5 \\
\hline & 37.0 & 5 & $45-65$ & $98.5 \pm 1.61$ & 3.7 \\
\hline \multirow{4}{*}{$\begin{array}{l}\frac{\text { Euplotes }}{\text { crassus }} \\
\left(10^{\circ}, 15 \mathrm{o} / 00\right)\end{array}$} & 30.1 & 8 & $25-33$ & $17.5 \pm 5.04$ & 81.1 \\
\hline & 32.0 & 8 & $25-32$ & $68.3 \pm 4.92$ & 20.4 \\
\hline & 34.5 & 6 & $24-35$ & $83.8 \pm 6.78$ & 19.8 \\
\hline & 37.0 & 3 & $30-31$ & $100.0 \pm 0.00$ & 0.0 \\
\hline \multirow{3}{*}{$\begin{array}{l}\text { E. } \\
\left(10^{\circ}, 250 / 00\right)\end{array}$} & 32.0 & 8 & $24-29$ & $8.3 \pm 2.20$ & 74.6 \\
\hline & 34.5 & 8 & $24-30$ & $79.0 \pm 8.20$ & 29.2 \\
\hline & 37.0 & 3 & $29-35$ & $100.0 \pm 0.00$ & 0.0 \\
\hline
\end{tabular}


Table 3. Cont'd.

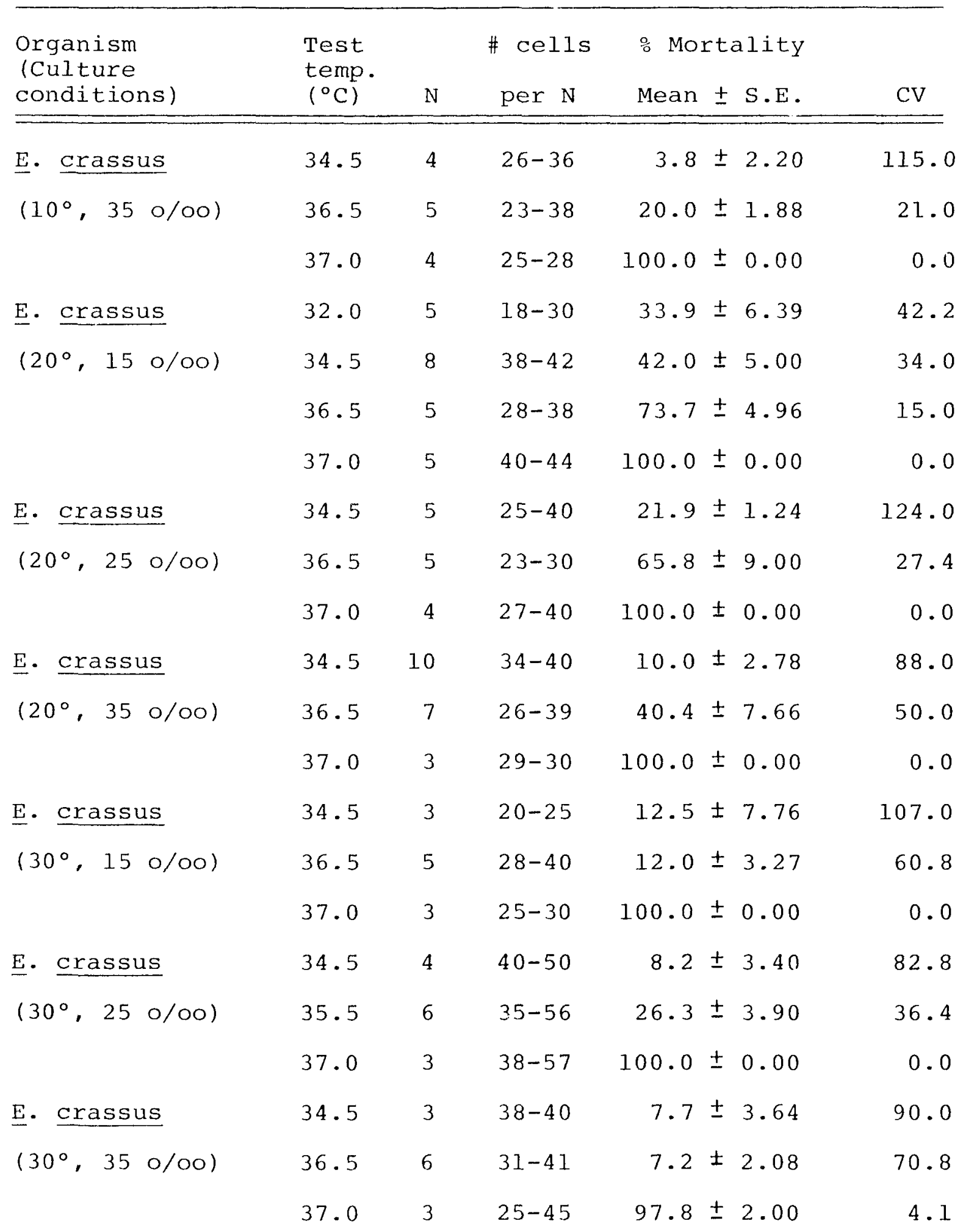


Table 3. Cont'd.

\begin{tabular}{|c|c|c|c|c|c|}
\hline $\begin{array}{l}\text { Organism } \\
\text { (Culture } \\
\text { conditions) }\end{array}$ & $\begin{array}{l}\text { Test } \\
\text { temp. } \\
\left({ }^{\circ} \mathrm{C}\right)\end{array}$ & $\mathrm{N}$ & $\begin{array}{l}\# \text { cells } \\
\text { per } N\end{array}$ & $\begin{array}{l}\text { \% Mortality } \\
\text { Mean } \pm \text { S.E. }\end{array}$ & $\mathrm{CV}$ \\
\hline E. harpa & 32.0 & 5 & $26-35$ & $3.7 \pm 2.48$ & 143.0 \\
\hline \multirow[t]{2}{*}{$\left(20^{\circ}, 15 \circ / 00\right)$} & 34.5 & 5 & $28-37$ & $21.9 \pm 6.43$ & 65.3 \\
\hline & 37.0 & 5 & $28-37$ & $100.0 \pm 0.00$ & 0.0 \\
\hline E. harpa & 34.5 & 5 & $21-30$ & $7.6 \pm 1.56$ & 46.0 \\
\hline \multirow[t]{2}{*}{$\left(20^{\circ}, 250 / 00\right)$} & 36.5 & 5 & $29-40$ & $15.0 \pm 3.00$ & 49.0 \\
\hline & 37.0 & 6 & $26-35$ & $97.9 \pm 1.30$ & 3.3 \\
\hline E. harpa & 34.5 & 6 & $26-34$ & $7.4 \pm 3.26$ & 108.1 \\
\hline \multirow{2}{*}{$\left(20^{\circ}, 350 / 00\right)$} & 36.5 & 6 & $29-36$ & $10.0 \pm 3.10$ & 76.0 \\
\hline & 37.0 & 3 & $23-29$ & $100.0 \pm 0.00$ & 0.0 \\
\hline E. raikovi & 34.5 & 6 & $32-40$ & $10.6 \pm 0.57$ & 14.0 \\
\hline \multirow[t]{2}{*}{$\left(20^{\circ}, 250 / 00\right)$} & 36.5 & 4 & $31-40$ & $28.0 \pm 1.00$ & 5.0 \\
\hline & 37.0 & 3 & $36-57$ & $100.0 \pm 0.00$ & 0.0 \\
\hline E. trisulcatus & 37.0 & 5 & $24-35$ & $17.7 \pm 2.72$ & 34.5 \\
\hline \multirow[t]{2}{*}{$\left(20^{\circ}, 250 / 00\right)$} & 38.4 & 5 & $26-42$ & $39.0 \pm 3.39$ & 19.5 \\
\hline & 40.9 & 3 & $32-37$ & $100.0 \pm 0.00$ & 0.0 \\
\hline$\frac{\text { Tachysoma }}{\text { saltans }}$ & 36.5 & 5 & $25-50$ & $44.7 \pm 7.65$ & 38.3 \\
\hline$\left(20^{\circ}, 250 / 00\right)$ & 37.0 & 5 & $80-250$ & $69.7 \pm 10.03$ & 34.1 \\
\hline
\end{tabular}

${ }^{a} \mathrm{CV}$ : Coefficient of variation 
Figure 27. Ranges of tolerance to acute heat stress.

1. Uronema marinum

2. Pleuronem coronatum

3. Strombidium sulcatum

4. Euplotes crassus

5. E. raikovi

6. E. harpa

7. E. trisulcatus

8. Condylostoma arenarium

9. Dexiotricha sp. 


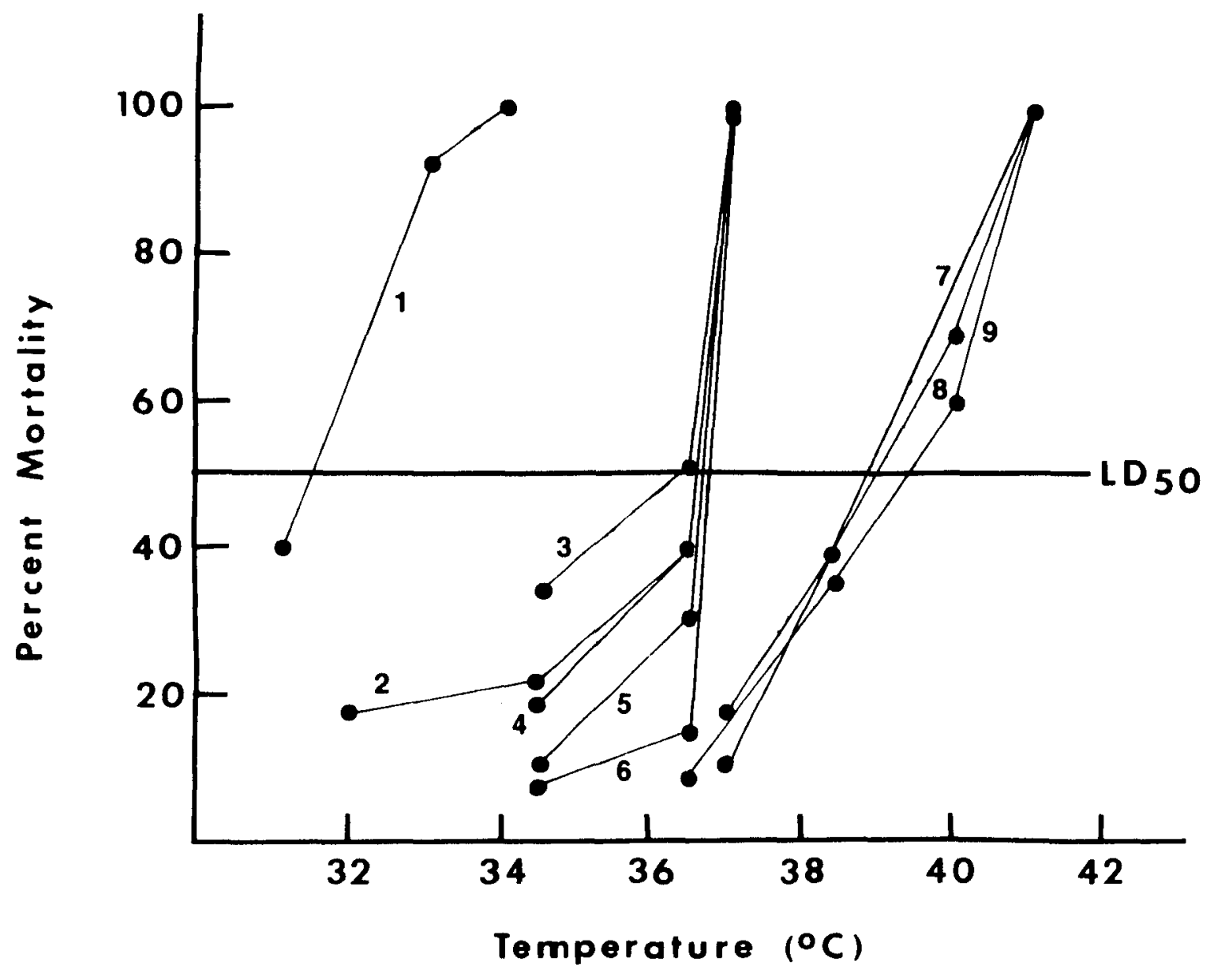


Table 4. TEMPERATURES OF OPTIMUM GROWTH, UPPER THERMAL LIMITS OF SIGNIFICANT GROWTH AND SURVIVAL, AND TOLERANCE TO ACUTE HEAT STRESS $\left(L D_{50}\right)$ FOR 12 SPECIES OF CILIATES

\begin{tabular}{|c|c|c|c|c|}
\hline \multirow[b]{2}{*}{ Organism } & \multicolumn{4}{|c|}{ Temperature $\left({ }^{\circ} \mathrm{C}\right)$} \\
\hline & $\begin{array}{l}\text { Temp. of } \\
\text { optimum } \\
\text { growth }\end{array}$ & $\begin{array}{l}\text { Upper } \\
\text { lim. of } \\
\text { signif. } \\
\text { growth }\end{array}$ & $\begin{array}{l}\text { Upper } \\
\text { lim. of } \\
\text { surv. }\end{array}$ & $\begin{array}{l}\text { Temp. } \\
\text { of } \\
\mathrm{LD}_{50}\end{array}$ \\
\hline Dexiotricha sp. & 34.0 & 37.0 & 38.0 & 39.3 \\
\hline$\frac{\text { Pleuronema }}{\text { coronatum }}$ & 31.0 & 32.0 & 33.0 & 36.5 \\
\hline Uronema marinum & 25.0 & 27.0 & 29.0 & 31.5 \\
\hline$\frac{\text { Condylostoma }}{\text { arenarium }}$ & 29.0 & 35.0 & 36.5 & 39.0 \\
\hline$\frac{\text { Strombidium }}{\text { sulcatum }}$ & 31.0 & 33.0 & 33.0 & 36.5 \\
\hline Euplotes alatus & 27.0 & 31.0 & 32.0 & 35.5 \\
\hline E. crassus & 29.0 & 32.0 & 33.0 & 36.6 \\
\hline E. harpa & 30.0 & 31.0 & 33.0 & 36.8 \\
\hline$\underline{\text { E. raikovi }}$ & 30.0 & 32.0 & 33.0 & 36.7 \\
\hline E. trisulcatus & 33.0 & 35.0 & 35.0 & 38.7 \\
\hline$\frac{\text { Tachysoma }}{\text { saltans }}$ & 34.0 & 35.0 & 35.0 & 36.8 \\
\hline$\frac{\text { Trachelostyla }}{\text { pediculiformis }}$ & 31.0 & 34.0 & 35.0 & 37.0 \\
\hline
\end{tabular}


of optimum growth ranged considerably. For instance, Uronema marinum reproduced most rapidly at $25^{\circ} \mathrm{C}$, whereas both Dexiotricha sp. and Tachysoma saltans attained maximum growth rates at $34^{\circ} \mathrm{C}$.

The upper thermal limits of significant growth lie within two degrees of the upper thermal limits of survival. Dexiotricha sp., for example, reproduces at $37^{\circ} \mathrm{C}$, and although it can tolerate $38^{\circ} \mathrm{C}$, it cannot divide at this temperature. Uronema marinum divides at $27^{\circ} \mathrm{C}$, but can only manage to survive at $29^{\circ} \mathrm{C}$. For several species, the temperatures recorded for upper thermal limits of significant growth and for survival were identical.

NUTRITION EFFECTS. When cultivated on single species of bacteria, Euplotes crassus was more sensitive to high temperatures than when grown on an assortment of bacteria (Fig. 28). Further, resistance to heat apparently is dependent on the particular species of bacteria on which the ciliates are cultivated. With the exception of the 4 minute heat exposure for $\underline{E}$. crassus grown on $\underline{P}$. cuprodurans vs. E. crassus grown on an assortment of bacteria, the differences between means are statistically significant both at the 95 and $99 \%$ confidence limits.

SALINITY EFFECTS. Dexiotricha sp., s. sulcatum and E. crassus reproduced at nearly all temperature-salinity combinations examined (Table 5). Without exception, generation time was inversely proportional to culture temperature, regardless of the salinity. Furthermore, the ranges of variation in 
Figure 28. Rate of survival of Euplotes crassus at $37-38^{\circ} \mathrm{C}$ : Effect of nutrition. Ciliates cultivated at $20^{\circ} \mathrm{C}$ on Arthrobacter marinus (....), Pseudomonas cuprodurans (-----) and on an assortment of bacteria (__). Vertical lines about the means are standard deviations. 


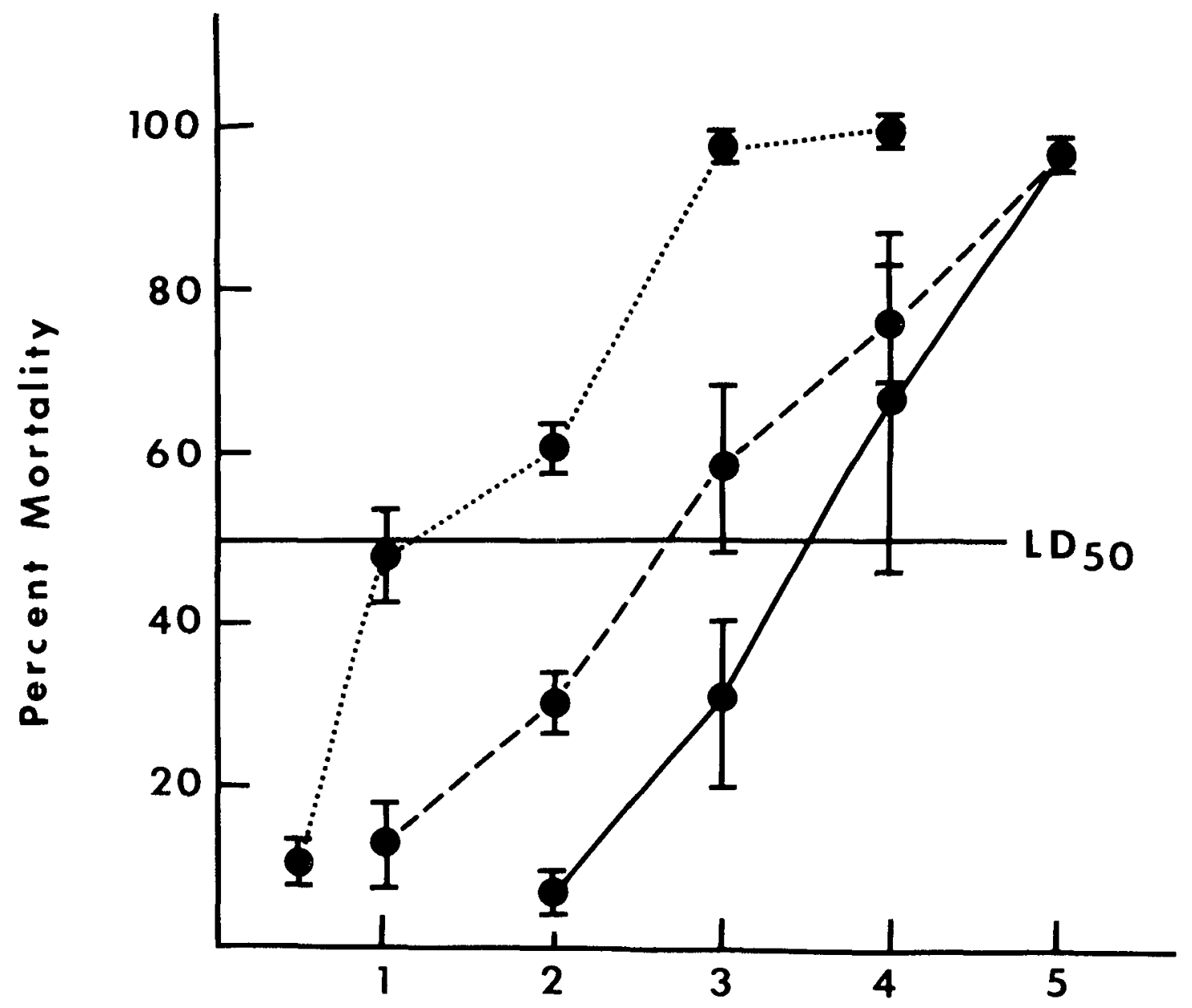

Time (minutes) 
Table 5. EFFECT OF TEMPERATURE AND SALINITY ON THE GENERATION TIME (IN HOURS) OF THREE SPECIES OF MARINE CILIATES

\begin{tabular}{|c|c|c|c|c|}
\hline \multirow[b]{2}{*}{ Organism } & \multirow{2}{*}{$\begin{array}{l}\text { Temp. } \\
\left({ }^{\circ} \mathrm{C}\right)\end{array}$} & \multicolumn{3}{|c|}{ Salinity $(0 / 00)$} \\
\hline & & 15 & 25 & 35 \\
\hline \multirow[t]{2}{*}{ Dexiotricha $\mathrm{sp}$. } & 15 & $65.8 \pm 11.6^{\mathrm{a}}$ & $65.1 \pm 1.2$ & $76.5(15.0)^{\mathrm{b}}$ \\
\hline & 30 & $9.3 \pm 0.5$ & $8.6 \pm 0.0$ & $8.7 \pm 0.9$ \\
\hline \multirow{3}{*}{$\frac{\text { Strombidium }}{\text { sulcatum }}$} & 15 & $60.4 \pm 12.1$ & $54.1 \pm 16.5$ & $42.6 \pm 1.5$ \\
\hline & 20 & $28.5 \pm 2.3$ & $16.8 \pm 3.5$ & $19.5 \pm 0.2$ \\
\hline & 30 & $12.9 \pm 1.0$ & $9.9 \pm 0.8$ & $7.9 \pm 0.9$ \\
\hline \multirow{3}{*}{$\frac{\text { Euplotes }}{\text { crassus }}$} & 10 & $53.3(0.0)$ & $59.4 \quad(0.0)$ & $62.4 \quad(5.9)$ \\
\hline & 20 & $15.2(0.5)$ & $15.4 \quad(0.3)$ & $15.4 \quad(0.5)$ \\
\hline & 30 & ------ & $10.1 \pm 0.9$ & $9.5 \pm 1.0$ \\
\hline
\end{tabular}


generation time among cultures at any particular salinity were non-overlapping (compare values in columns in Table 5). There also appears to be a decrease in variability of generation time with culture temperature at nearly all salinities tested. In marked contrast, however, there was a higher degree of variability in generation time among cultures at any particular temperature; that is, with few exceptions most pairs of values at any particular temperature were within one standard deviation of each other. In addition, there appeared to be no consistent trend in variability as a function of salinity. An obvious exception is the apparent relationship between increased salinity and decreased genera-

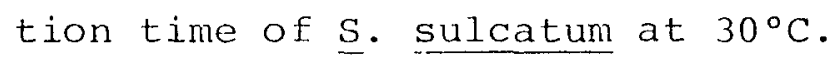

At $30^{\circ} \mathrm{C}$, low salinity inhibited E. crassus reproduction; i.e., fewer than 25\% of the attempts at culturing E. crassus at $30^{\circ} \mathrm{C}$ and $150 / 00$ were successful. Strombidium sulcatum appears to be inhibited almost as much by that combination of salinity and temperature $\left(30^{\circ} \mathrm{C}\right.$ and $\left.15 \mathrm{o} / 00\right)$; the values in Table 5 were obtained only after several attempts. Dexiotricha sp. showed no indication of reproduction being restricted at $30^{\circ} \mathrm{C}$ and 15 o/oo; all cultures developed without difficulty and with minimum variability. However, at certain temperatures and salinities, a positive correlation exists between culture salinity and heat shock resistance. For example, when $\underline{E}$. crassus is cultured at $10^{\circ}$ and $15^{\circ} \mathrm{C}$, the differences in mortality rates between organisms grown at salinities of 15 , 25 and $350 / 00$ are significant $(P=0.05)$ at shock temperature 
of $30^{\circ}$ and $32^{\circ} \mathrm{C}$. At heat shocks of $34.5^{\circ}$ and $36.5^{\circ}$ only ciliates cultivated at 35 \%/oo were significantly more resistant (Figs. 29, 30). The influence of salinity on heat resistance diminished as $\underline{E}$. crassus was cultivated at $20^{\circ}$ and $30^{\circ} \mathrm{C}$ (Figs. 31,32 ). At heat shocks of $37^{\circ} \mathrm{C}$ neither salinity nor culture temperature regimes influenced the resistance of E. crassus to heat stress. Figure 33 summarizes the effects of salinity-temperature interaction on the heat resistance of $E$. crassus.

In Figure 34 the average generation time of seven species of ciliates is plotted as a function of incubation temperatures. Generally, mean generation time decreased as ciliates were cultivated at successively higher temperatures until their individual growth optima were reached. Beyond their temperatures of optimum growth they either stopped reproducing (such as E. harpa where only a few individuals divided at temperatures above $30^{\circ} \mathrm{C}$ ) or divided at much slower rates.

INFLUENCE OF TEMPERATURE ON TWO-SPECIES INTERACTIONS. At the low food level (0.001\% PPY), isolated populations of Strombidium sulcatum achieved nearly identical maximum numbers (approximately $400 / \mathrm{ml}$ ) at rates that were dependent upon culture temperature (see Figs. 35-37); population growth phase occurring in nine days at $15^{\circ} \mathrm{C}$, five days at $28^{\circ} \mathrm{C}$, and in only four days at $30^{\circ} \mathrm{C}$. In mixed cultures with Euplotes crassus, however, S. sulcatum reached different population maxima at different temperatures (approximately 
Figure 29. Effect of salinity on the heat resistance of Euplotes crassus cultivated at $10^{\circ} \mathrm{C}(\ldots .15 \% / 00$, ---- 25 o/00, 35 o/00). 
43

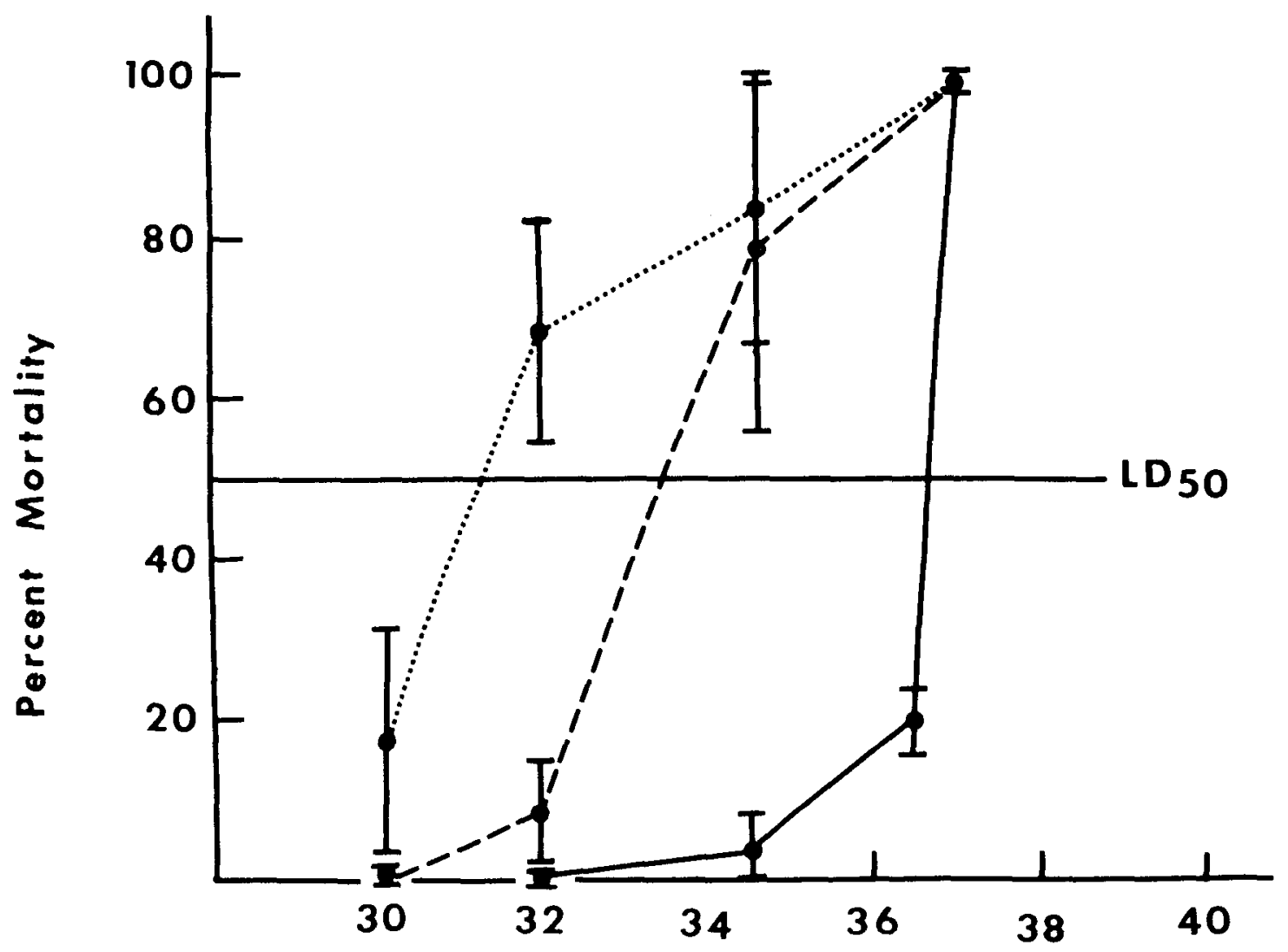

Test Temperature ( $\left.{ }^{\circ} \mathrm{C}\right)$ 
44

Figure 30. Effect of salinity on the heat resistance of Euplotes crassus cultivated at $15^{\circ} \mathrm{C}(\ldots .150 / 00$, $----250 / 00,-35 \% / 00)$. 


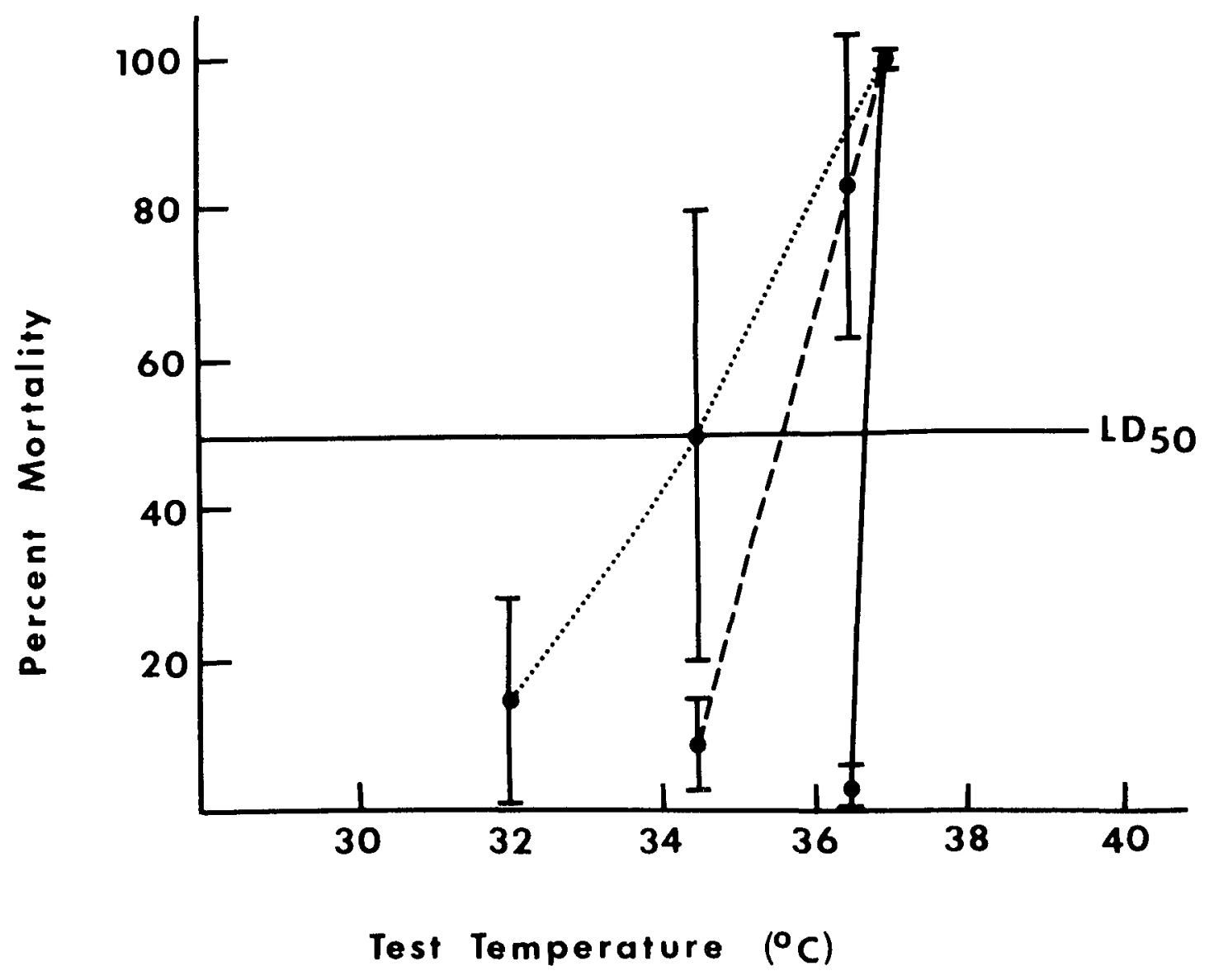


Figure 31. Effect of salinity on the heat resistance of Euplotes crassus cultivated at $20^{\circ} \mathrm{C}(\ldots .150 / 00$, -- $250 / 00,-35 \% / 00)$. 


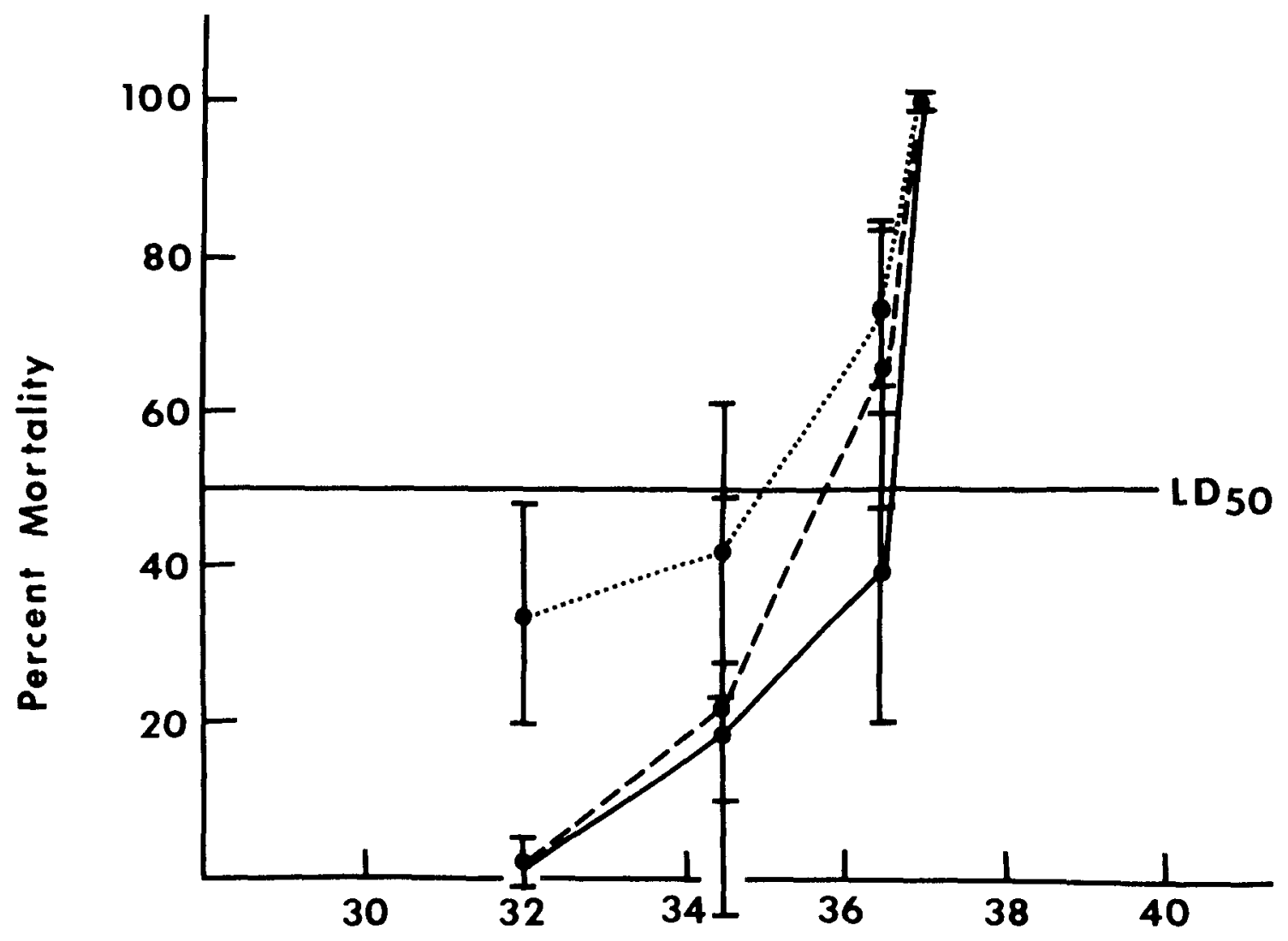

Test Temperature (OC) 
Figure 32. Effect of salinity on the heat resistance of Euplotes crassus cultivated at $30^{\circ} \mathrm{C}(\ldots .15 \% / 00$, $----250 / 00,-350 / 00)$. 


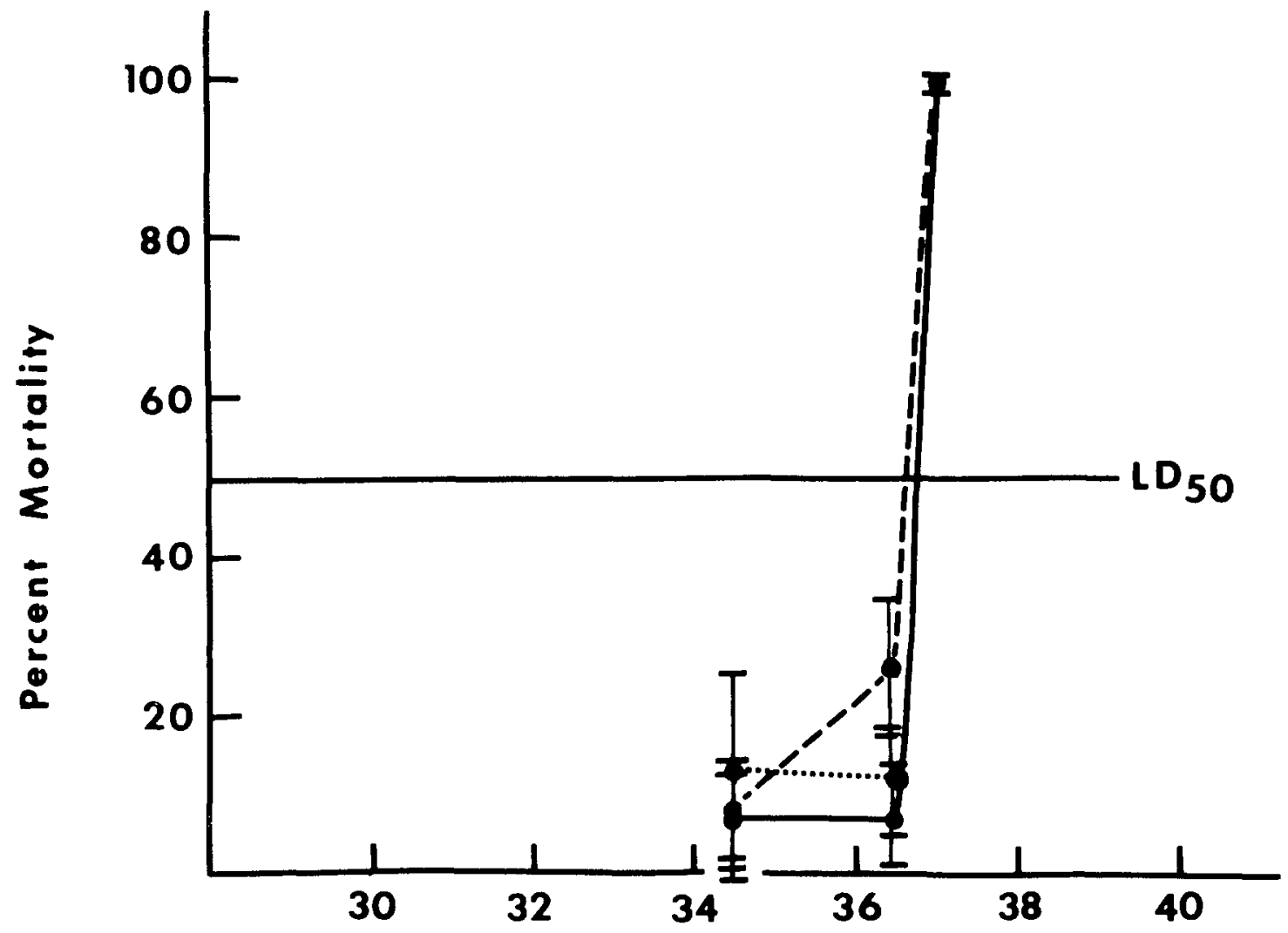

Test Temperature ( $\left.{ }^{\circ} \mathrm{C}\right)$ 
Figure 33. Influence of temperature and salinity on the heat resistance of Euplotes crassus. 


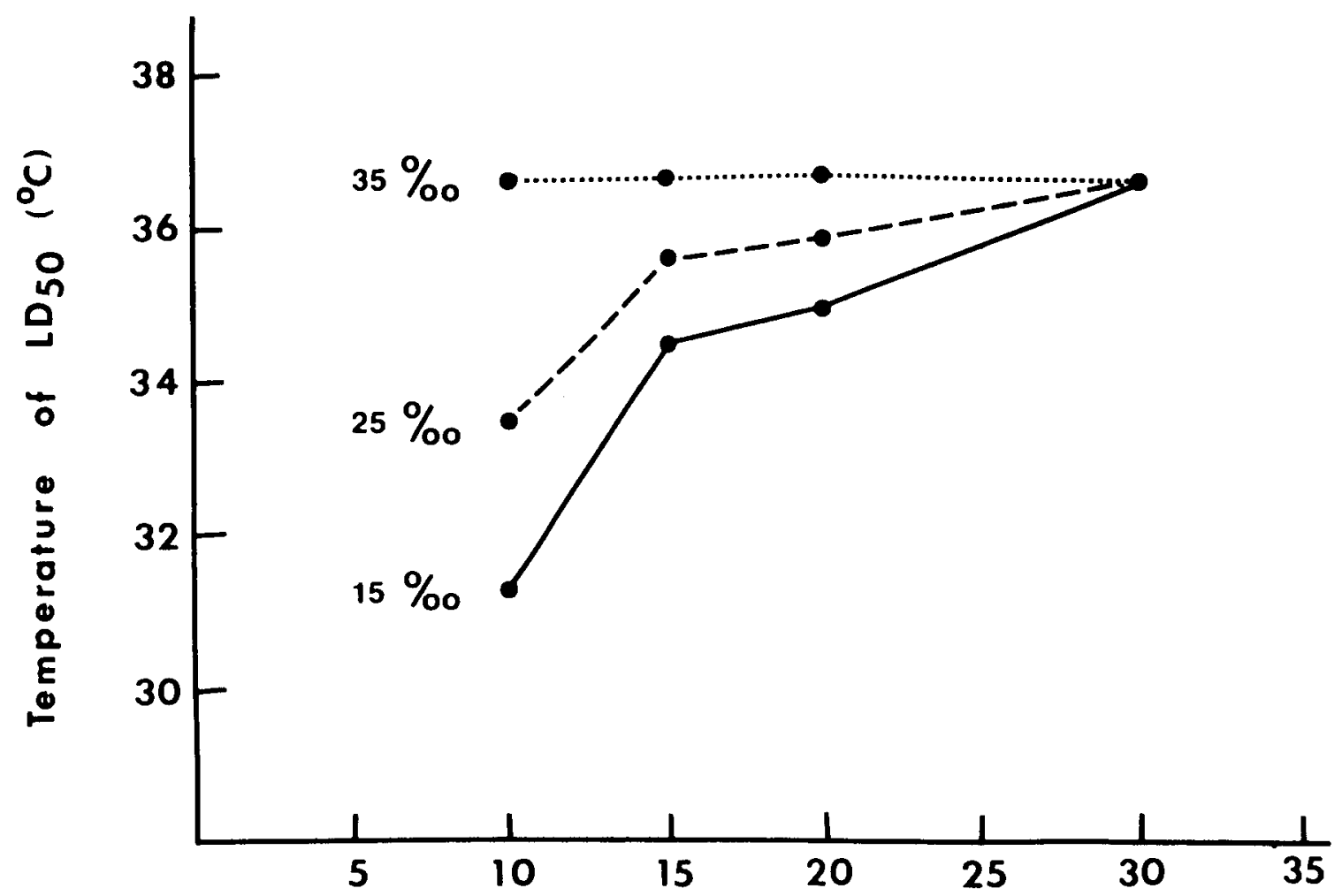

Acclimation Temperature $\left({ }^{\circ} \mathrm{C}\right)$ 
Figure 34. Generation time of seven species of ciliates at different temperatures. 


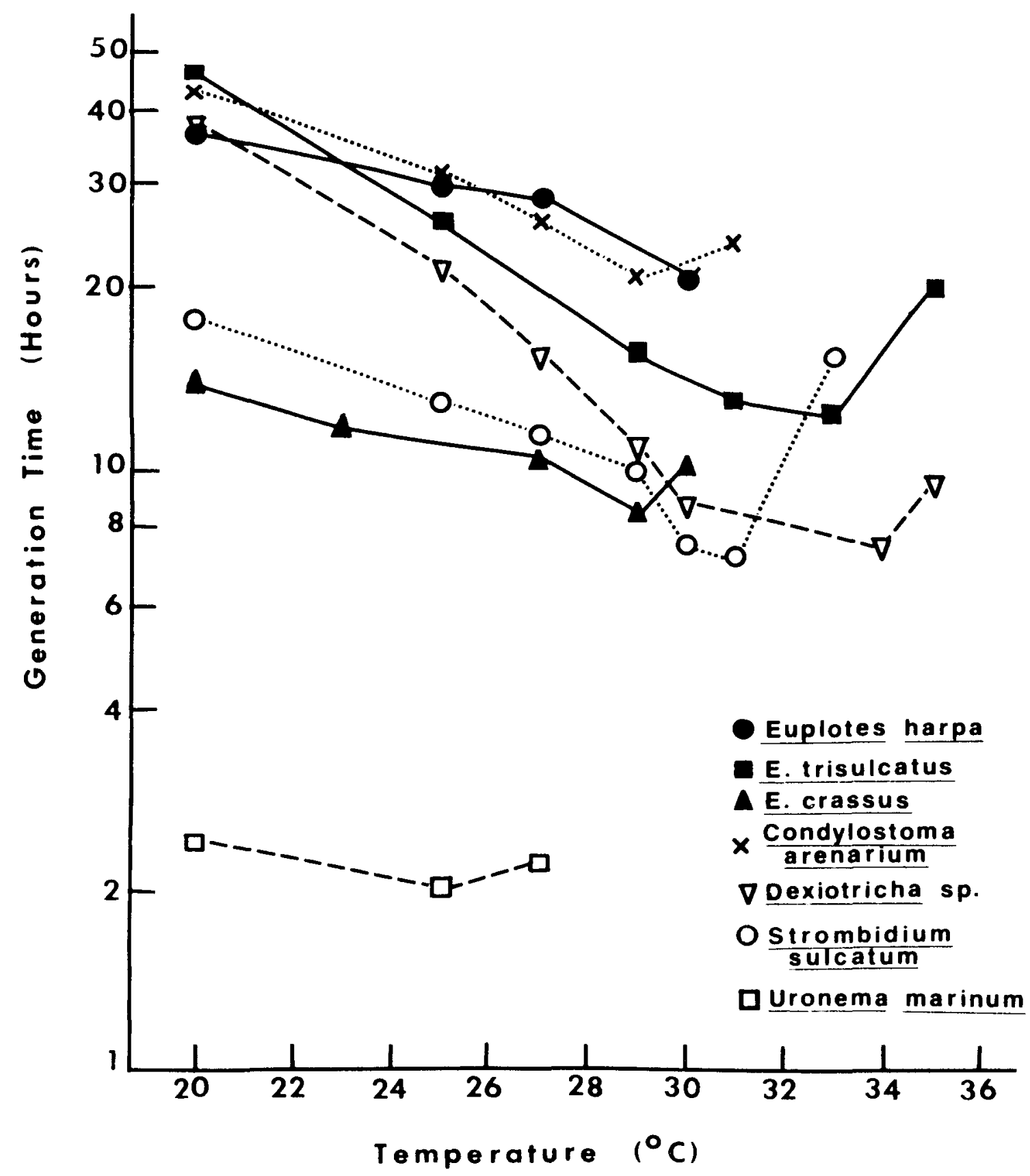


54

Figure 35. Interaction between Euplotes crassus and Strombidium sulcatum at $15^{\circ} \mathrm{C}$ and $0.001 \%$ proteose peptone and yeast extract. 


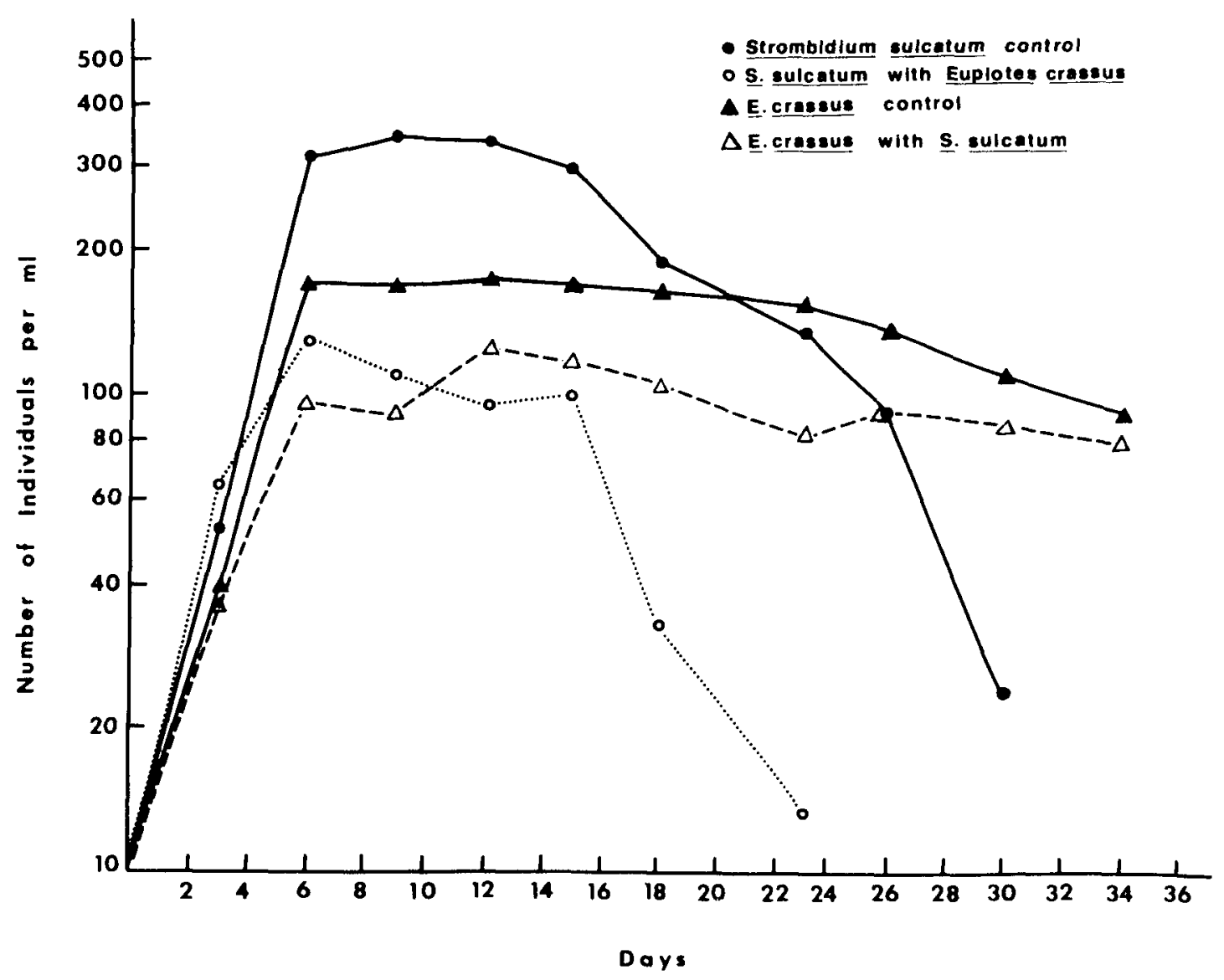


Figure 36. Interaction between Euplotes crassus and Strombidium sulcatum at $28^{\circ} \mathrm{C}$ and $0.001 \%$ proteose peptone and yeast extract. 


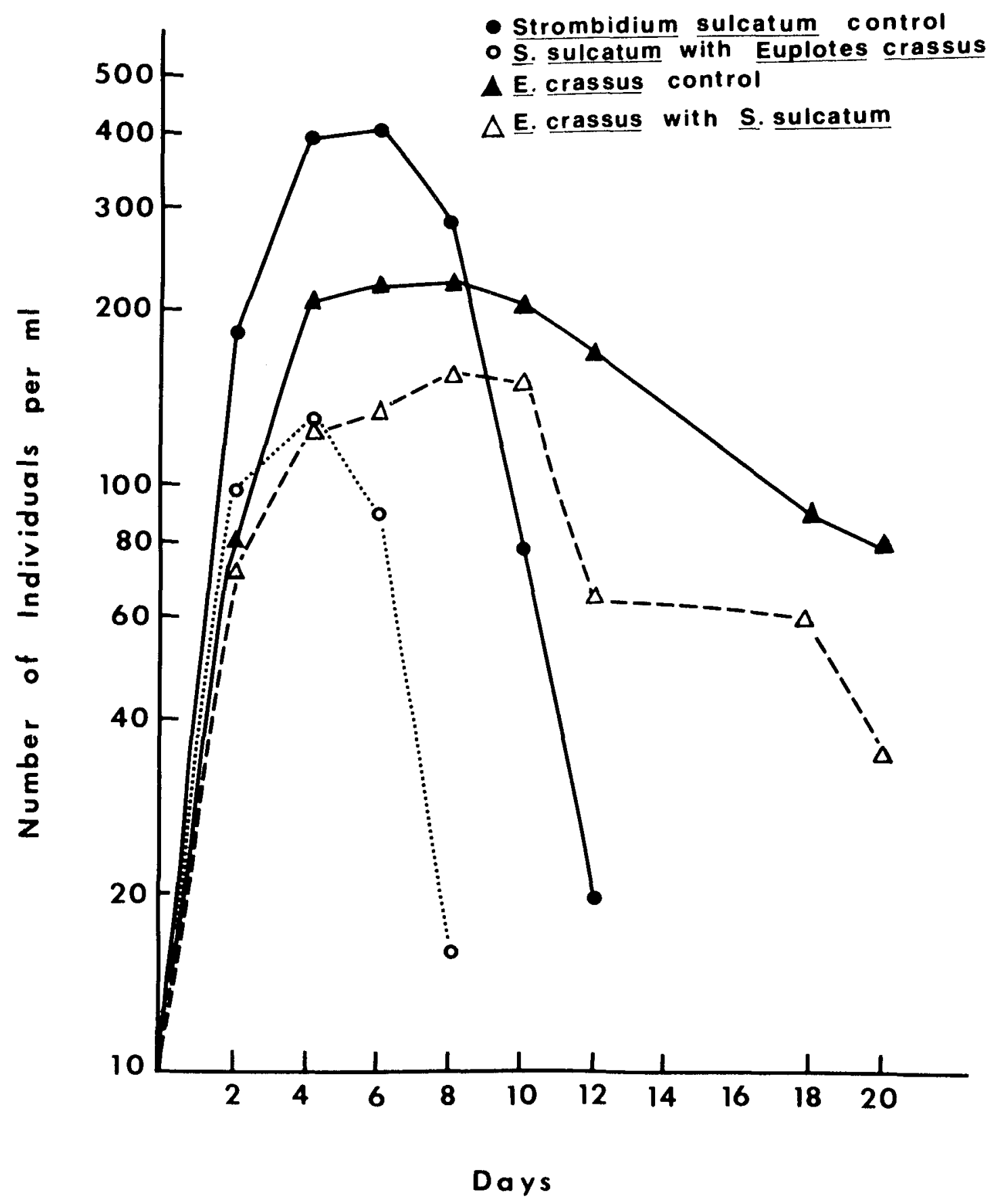


Figure 37. Interaction between Euplotes crassus and Strombidium sulcatum at $30^{\circ} \mathrm{C}$ and $0.001 \%$ proteose peptone and yeast extract. 


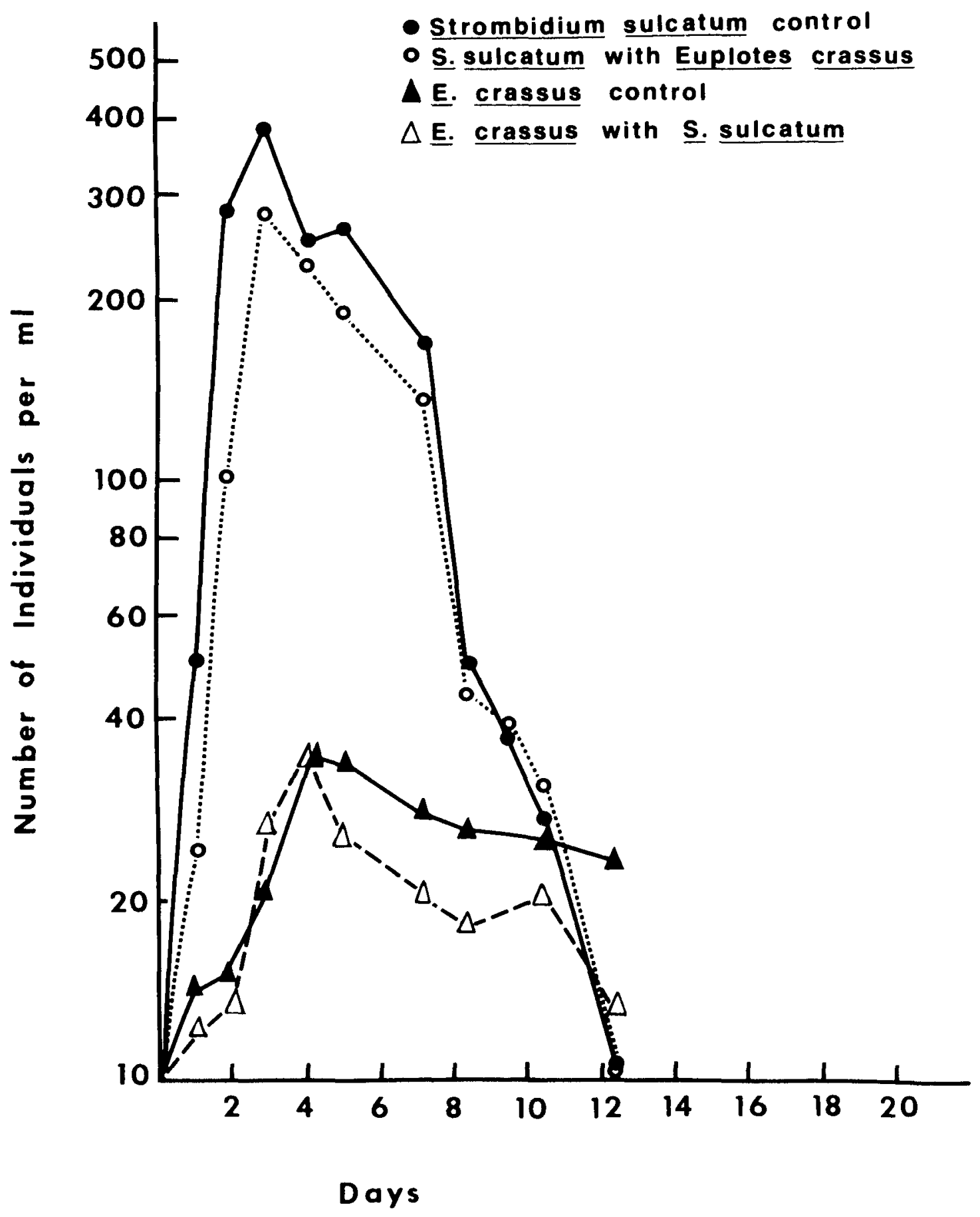


$130 / \mathrm{ml}$ when cultivated at $15^{\circ}$ or $28^{\circ} \mathrm{C}$, but reaching $280 / \mathrm{ml}$ at $30^{\circ} \mathrm{C}$, nearly as high as when grown in isolation). These data suggest temperature-related differences in the effect of E. crassus upon S. sulcatum at $28^{\circ}$ and $30^{\circ} \mathrm{C}$.

At low food level, isolated populations of E. crassus achieved nearly identical maximum numbers (approximately 175$200 / \mathrm{ml}$ ) at culture temperatures of $15^{\circ}$ and $28^{\circ} \mathrm{C}$, but attained only a population size of $35 / \mathrm{ml}$ when grown at $30^{\circ} \mathrm{C}$. In mixed

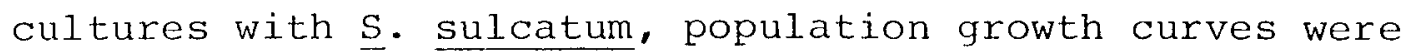
similar to those of isolated E. crassus cultures, but generally with slightly lower population numbers. These data suggest a relatively limited effect of $\underline{S}$. sulcatum upon $\underline{E}$. crassus growth, compared with temperature effects at this food level.

At the higher food level. (0.015\% PPY), isolated populations of $\underline{S}$. sulcatum reached significantly higher population densities faster at $28^{\circ} \mathrm{C}$ than at $15^{\circ} \mathrm{C}$ (Figs. 38 , 39). In mixed cultures with E. crassus, similar results occurred, but population densities were only about half that of isolated cultures. These data suggest no obvious temperature related difference in the effect of $\underline{E}$. crassus

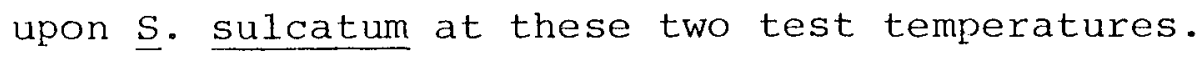

Population densities achieved by culture of E. crassus at this food level were nearly identical, regardless of temperature and the presence or absence of $\underline{S}$. sulcatum. These data suggest a relatively limited effect of $\underline{\text { s. }}$ sulcatum upon E. Crassus growth.

Since there appeared to be a lesser effect of 
Figure 38. Interaction between Euplotes crassus and strombidium sulcatum at $15^{\circ} \mathrm{C}$ and 0.015 응 proteose peptone and yeast extract. 


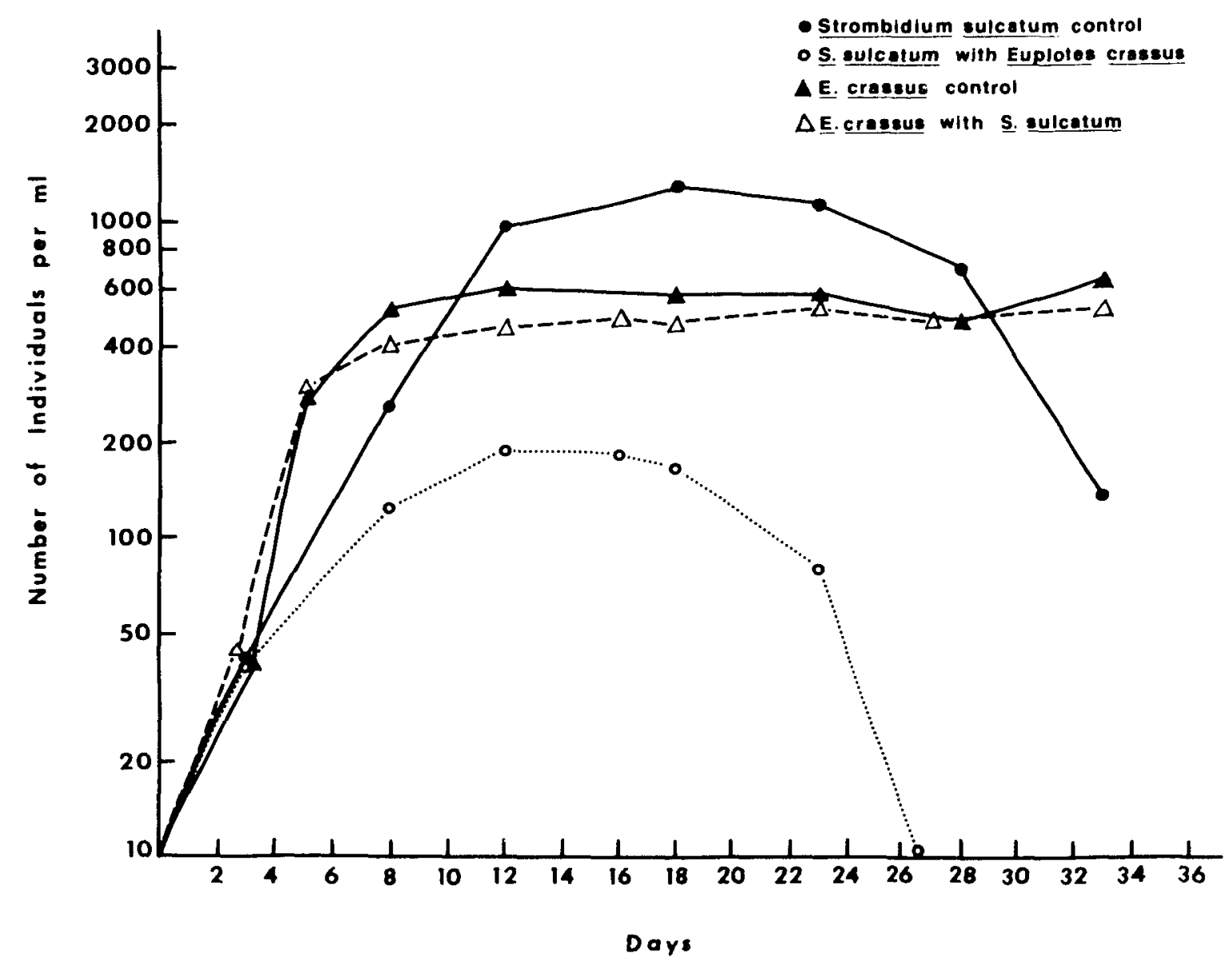


Figure 39. Interaction between Euplotes crassus and Strombidium sulcatum at $28^{\circ} \mathrm{C}$ and $0.015 \%$ proteose peptone and yeast extract. 


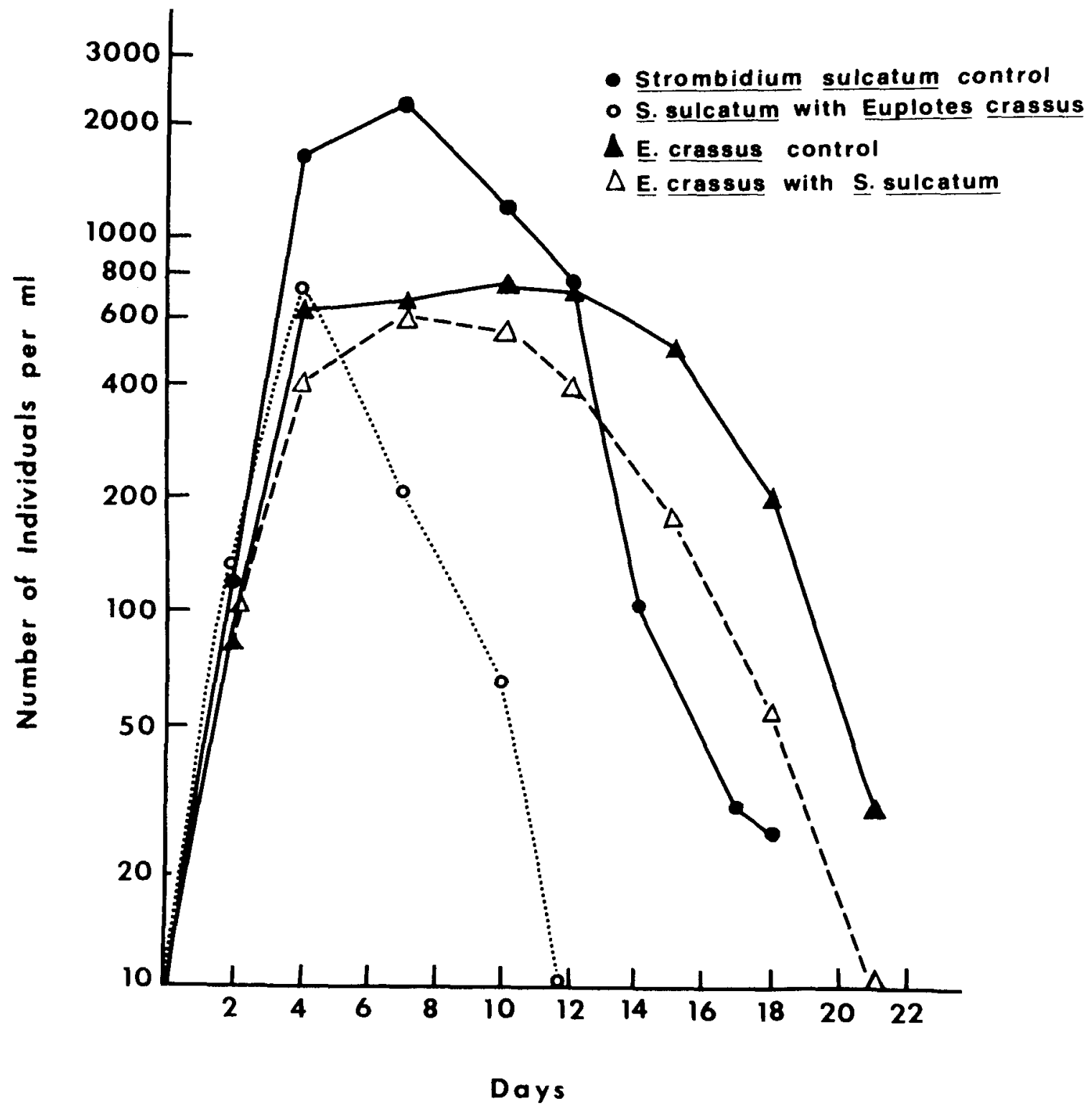


S. sulcatum upon E. crassus at these temperatures at a food level of $0.015 \%$ compared with $0.001 \%$, no two-species interactions were observed at $30^{\circ} \mathrm{C}$ at high food level. That is, at the higher food level, E. crassus populations showed no indications of being influenced by the presence of $\underline{S}$. sulcatum, hence there appeared no need to determine the temperature effects upon their population growth rate at $30^{\circ} \mathrm{C}$.

Similar observations of isolated and mixed populations of two congeners, Euplotes crassus and E. harpa, yielded strikingly different results (Figs. 40 and 41 ). At the food concentration employed (0.001\% PPY), and at both culture temperatures $\left(15^{\circ}\right.$ and $\left.28^{\circ} \mathrm{C}\right)$, population growth curves for isolated and mixed populations were not consistent; neither species affected the growth and survival of the other.

In summary, temperatures of optimum growth ranged widely among the different species of ciliates examined. Both temperature optima and upper thermal limits of growth are close to thermal limits of survival. Heat sensitivity depended not only upon the variety, but also on the quality or type of nutrients available to $\underline{E}$. crassus. When cultivated at low temperatures, heat resistance in E. crassus increased with increasing salinity. Acclimation to high temperatures similarly increased its resistance to sudden heat stress. The ability of Dexiotricha sp., S. sulcatum and E. crassus to reproduce over a wide range of temperatures and salinities demonstrates the capacity of these organisms to tolerate and to adjust to extreme changes in environmental 
Figure 40. Interaction between Euplotes crassus

and E. harpa at $15^{\circ} \mathrm{C}$ and $0.001 \%$

proteose peptone and yeast extract. 


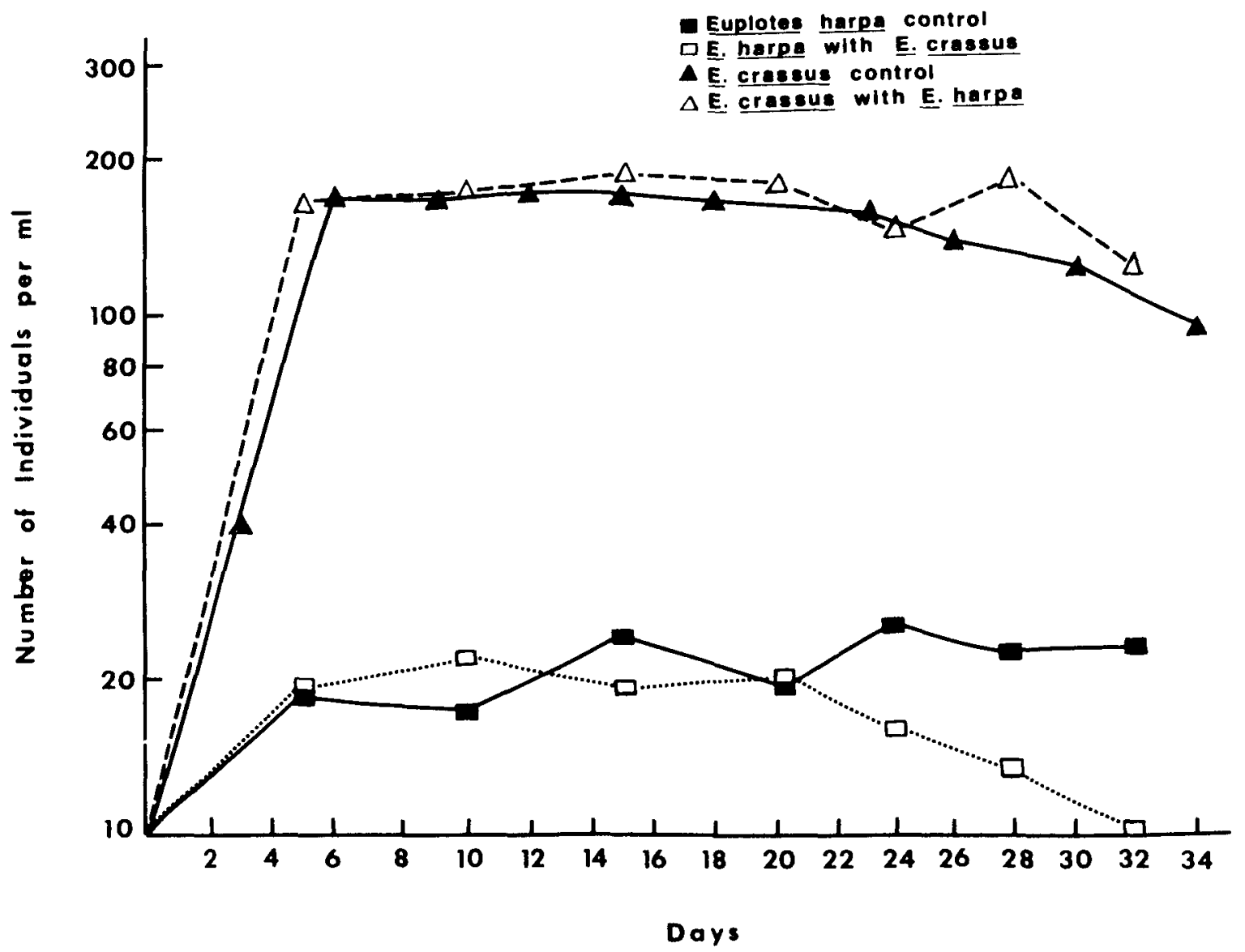


68

Figure 41. Interaction between Euplotes crassus

and E. harpa at $28^{\circ} \mathrm{C}$ and $0.001 \%$

proteose peptone and yeast extract. 


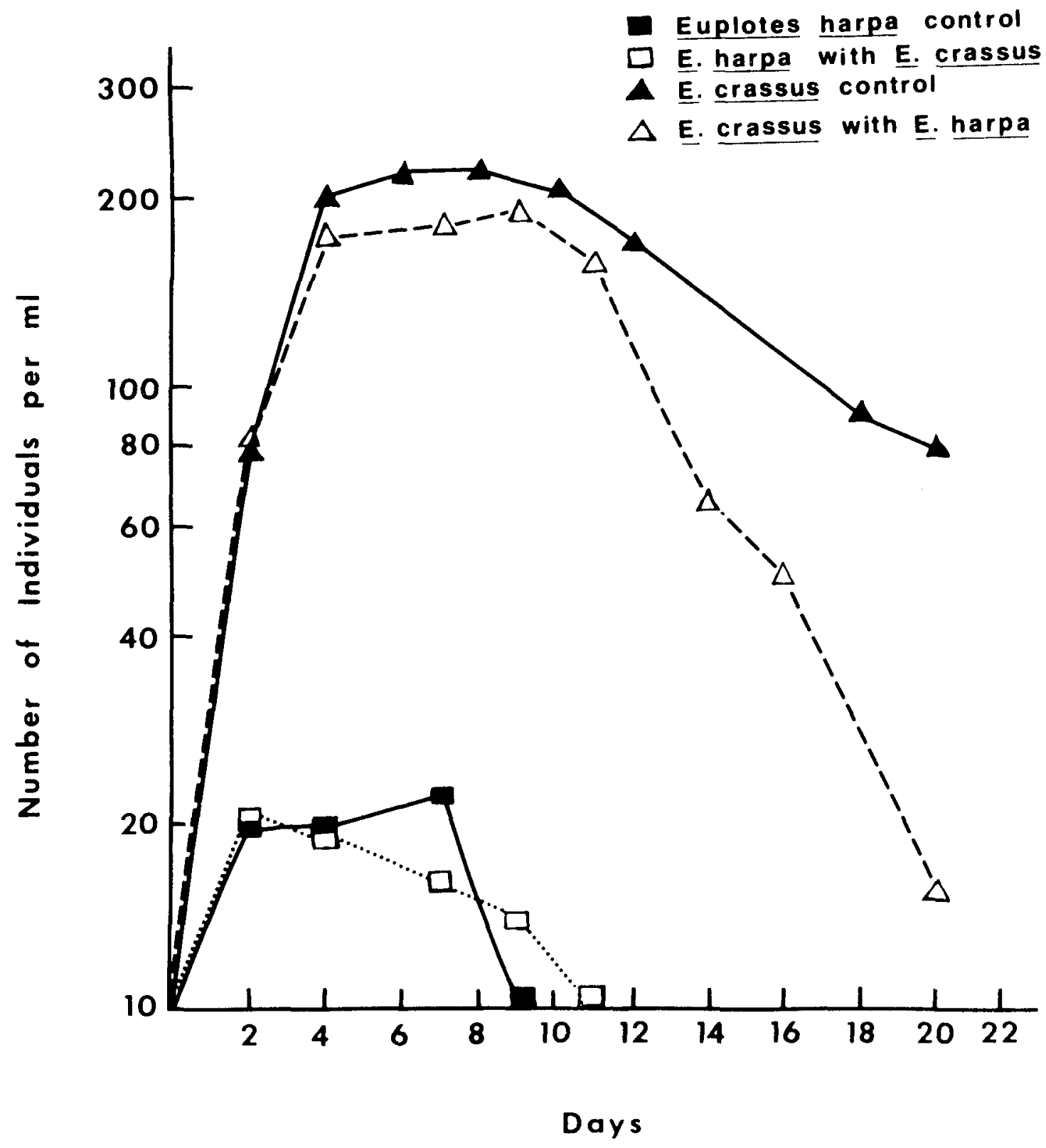


conditions. However, as shown with $\underline{\mathrm{E}}$ crassus and to a lesser

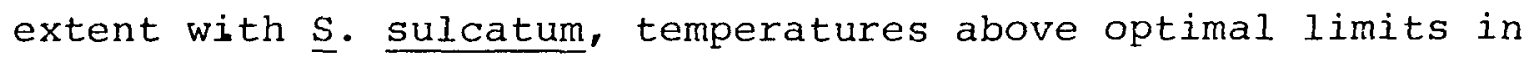
conjunction with low salinities inhibited reproduction.

Thermal changes had little influence on the competitive

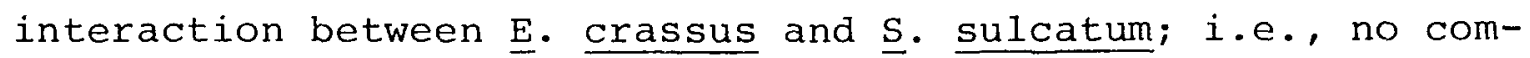
petitive advantage was given to either species as a result of increasing temperatures. Further, temperature elevations beyond the growth optimum of E. crassus actually reduced any competitive effects of this species over $\underline{s}$. sulcatum. Changing the food concentration only affected the total number of organisms produced; higher densities of ciliates were attained at the higher food level than at the lower, again without influencing competitive interaction. Temperature effects on the interaction between two species of Euplotes are inconclusive. 


\section{DISCUSSION}

I have demonstrated that ciliates are particularly sensitive to sudden elevations in temperature, especially near their lethal limits. Additionally, thermal requirements for growth and survival are influenced by both biotic and abiotic factors. Before discussing the effects of these factors on the heat sensitivity of ciliates, a few comments concerning my observations on the behavioral responses during heat tolerance determinations may be appropriate.

The pattern of behavior elicited by heat shock was similar among the various species of ciliates studied. During the initial 30-40 seconds of heat treatment, the rate of locomotion accelerated considerably, eventually becoming erratic; i.e., uncoordinated or lacking normal direction. Similar observations of accelerated locomotion were made by Tawada \& Miyamoto (1973) and Tawada \& Oosawa (1972) on the response of Paramecium caudatum to thermal changes. This behavioral response is considered by these and other investigators to be a mechanism manifested in the dynamic properties of the cell membrane as a receptor for detecting optimal temperature conditions and as an avoidance mechanism from lethal conditions (see Jahn \& Bovee, 1967).

Sleigh (1956) observed that increasing temperatures increased ciliary beat frequency in stentor polymorphus, and that this was accompanied by reduction in metachronal wave length and increased wave velocity. The frequency and wave 
velocity increased steadily with temperature up to $25-28^{\circ} \mathrm{C}$, above which rates of increase declined. Observations by Machemer (1972) further show that reduction of temperature causes a counterclockwise shift in beat direction in Paramecium multimicronucleatum. Such temperature-related alterations of ciliary activity have been associated with membrane-regulated changes of intracellular calcium concentration (Dryl, 1970; Eckert, 1972; Murakami \& Eckert, 1972 and Satir, 1975). External stimuli, whether chemical, mechanical, electrical, thermal, or alteration in viscosity of culture medium, induce changes in membrane potential which in turn regulate the rate of calcium uptake by the cell. Murakami \& Eckert (1972) demonstrated that increased influx of intracellular $\mathrm{Ca}^{2+}$ due to mechanical stimulation of the cell membrane induced higher frequency of ciliary beating. These and other researchers hypothesize that the role of calcium in ciliary activity is analogous to that played in the activity of muscle ATP-ase --- ATP system (see also Dryl, 1970 and sleigh, 1970).

In ciliates where coagulation of cytoplasmic proteins did not occur such as strombidium sulcatum, Trachelostyla pediculiformis and Condylostoma arenarium, cytolysis, vesiculation or complete fragmentation of the cell was prominent. Coagulation at death was typical among Euplotes. Contortions of the organism, cytoplasmic bulges or extrusions were most evident in $C$. arenarium. Just prior to death or during highly stressful sublethal temperatures, impaired 
locomotion was characterized by spinning or tight circling movements as in Euplotes or by jerky back and forth movements as in $T$. pediculiformis.

Although ciliary activity was in some cases observed in immobile ciliates, lack of mobility of the organism as a whole was chosen as the criterion for determining death for several reasons. First, it was easier and quicker to determine cell immobility rather than to ascertain whether or not membranelles or cilia were active, particularly in the smaller organisms such as Uronema marinum and Tachysoma saltans. Secondly, ciliary activity persisted even in ciliates that had undergone cytolysis or fragmentation, and therefore I felt was not as reliable a criterion as loss of mobility. lastly, in studies where many ciliates were subjected to stress of one form or another (e.g., Giese, 1938 and Nyberg, 1974), lack of mobility was relied upon as a criterion for death.

The high sensitivity of ciliates to elevated temperatures is suggested by the small differences between temperatures of $\mathrm{LD}_{50}$ and $\mathrm{LD}_{100}$. In several replicates, during the course of heat shock experiments, an increase of $1-2^{\circ} \mathrm{C}$ meant the difference between $0 \%$ and $100 \%$ mortality. Similar sensitivities to high thermal stress were observed for several species of estuarine bivalves (Kennedy \& Mihursky, 1971). Hedgpeth \& Gonor (1969) point out that the distribution and abundance of many invertebrates, especially those that occur in large populations, are affected by small 
fluctuations in environmental temperatures. According to them, such knowledge is necessary for the understanding of any adverse affects of artificial thermal changes on populations of organisms.

However, ciliates exhibit wide ranges of sensitivity in response to acute heat stress. Uronema marinum was the most sensitive; its $L_{50}$ was recorded at $31.5^{\circ} \mathrm{C}$ (Table 4 , Fig. 27). Dexiotricha sp. and C. arenarium had the highest resistance to heat shock; their $L_{50}$ 's registered at $39.3^{\circ}$ and $39^{\circ} \mathrm{C}$, respectively. These temperatures are lower than those reported by Cairns (1972) for freshwater ciliates, where the mean for Spirostomum ambiguum was $46.8^{\circ} \mathrm{C}$, that for Colpidium colpoda was $43.4^{\circ} \mathrm{C}$, for stentor coeruleus it was $48.2^{\circ} \mathrm{C}$, for Tetrahymena pyriformis, $45.9^{\circ} \mathrm{C}$, and for Paramecium multimicronucleatum, $42.9^{\circ} \mathrm{C}$. These discrepancies may be attributed to the fact that Cairns acclimated his organisms to $25^{\circ} \mathrm{C}$, whereas I cultured my ciliates at $20^{\circ} \mathrm{C}$. Also, his ciliates were obtained from a commercial source where the culture media provided may be richer in nutrients than that contained in the simple seawater-rice medium employed in the present investigation.

When the difference betwen the temperature of optimum growth and the temperature of $\mathrm{LD}_{50}\left(\mathrm{~T}_{\mathrm{LD}_{50}}-\mathrm{T}_{\text {opt. }}\right)$ is plotted against the temperature of optimum growth, an inverse linear relationship is evident (Fig. 42). A low correlation $(r=0.210)$ was obtained when U. marinum data were included in the computation of regression analysis (regression 1ine A, Fig. 42). When 
Figure 42. Relationship between temperature of optimum growth and temperature of $\mathrm{LD}_{50}$ - (Regression lines fitted by the method of least squares, $y=a+b x$. Line A includes Uronema marinum data, $\mathrm{a}=19.78, \mathrm{~b}=-0.44, \mathrm{~N}=12$. Line $\mathrm{B}$ excludes Uronema marinum data, $a=28.5$, $\mathrm{b}=-0.72, \mathrm{~N}=11$ ). 


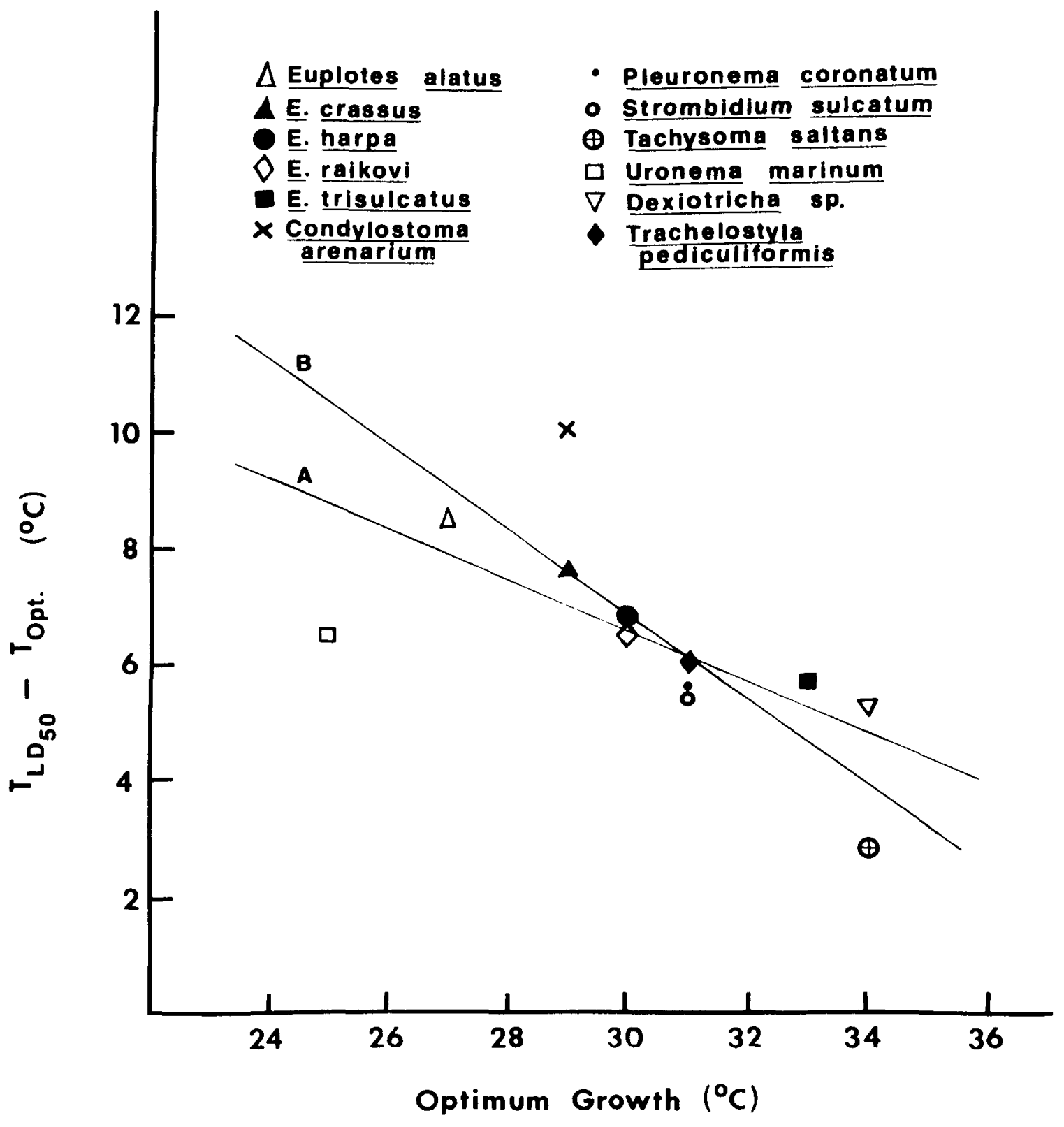


U. marinum was not considered (regression line B), the correlation became significant $(P=0.05)$. This suggested that $\underline{U}$. marinum was indeed significantly different from other ciliates in its sensitivity to heat stress. However, it was further noted that the correlation of regression analysis was statistically significant also when $\underline{C}$. arenarium, for example, is not considered in the analysis. This analysis, therefore, does not really provide a statistical measure to support the observed differences in heat sensitivity. Nevertheless, the recorded differences in $\mathrm{LD}_{50}$ (Fig. 27) and generation time as a function of temperature (Fig. 34) provide sufficient evidence that U. marinum is strikingly different from other ciliates in its thermal sensitivity. Further, Strombidium sulcatum, Euplotes trisulcatus and Tachysoma saltans are of comparable dimensions, and yet are considerably more resistant to acute heat stress than $\underline{U}$. marinum. Therefore, differences in response to temperature changes do not appear to be a function of either cell size, cell shape, nucleo-cytoplasm ratio, nuclear configuration, or proximity of nucleus to cell membrane.

As noted by Fenchel (1968b), maximal reproductive rates are generally inversely correlated with cell size. Uronema marinum, the smallest ciliate tested, had the shortest division time (Fig. 34). Condylostoma arenarium and E. harpa, both among the largest ciliates studied, took longer to divide than the other ciliates. The correlation between cell size and generation time does not hold, however, for $\underline{\text { s. sulcatum, }}$ $\underline{E}$ trisulcatus and E. crassus. The former two species are 
much smaller than E. crassus (see Table 1) and yet have longer generation times; the difference in generation time between E. trisulcatus and E. crassus being considerable. Therefore, factors other than cell size or cell shape must be considered in order to explain both the differences and/or similarities in generation time and sensitivities to high temperatures. Evidence from other studies indicate that such factors are physiologically related. For example, the nature and properties of enzyme systems and proteins play a significant role in the temperature requirements and adaptations of psychrophilic, mesophilic and thermophilic bacteria (Christophersen, 1967, 1973; Farrel \& Rose, 1967). Nutritional requirements of protozoa can be modified by increases in temperature. In the flagellate Ochromonas malhamensis, for example, a shift of culture temperature from $34^{\circ}$ to $38^{\circ} \mathrm{C}$ increased the requirement for thamine 1000 times, and increased the $B_{12}$ requirement by approximately 3000 times (Ha11, 1965, 1967). Chemically-defined culture medium supplemented with nucleic acid derivatives enhanced Tetrahymena pyriformis growth at $37^{\circ} \mathrm{C}$ and further addition of phospholipids permitted equivalent growth at $39^{\circ}$ and $1 / 3$ of that at $40^{\circ} \mathrm{C}$ (Rosenbaum et al., 1966). Cytochemical investigations on Blepharisma intermedium have shown that conditions are optimal for cell division when acclimated to $28^{\circ} \mathrm{C}$ (Kasturi et al., 1969). At that temperature, required quantities of glycogen, basic proteins, lipids, enzymes and phosphatases are present. However, at $30^{\circ} \mathrm{C}$, metabolic patterns were altered. Glycogen 
reserves, proteins and lipids were diminished, enzyme activity decreased and changes in the free amino acids were observed with the simultaneous blockage of cell division.

The thermal resistance of E. crassus was shown to vary according to the quantity and type of bacteria on which it was cultivated (see Results). Undoubtedly, the assortment of nutrients provided by the rich bacterial growth in the unfiltered seawater confers greater heat resistance to $\underline{E}$. crassus than the limited diet provided by single species of bacteria. Perhaps for similar reasons, E. Crassus demonstrates more resistance to heat when cultivated on Pseudomonas cuprodurans than when cultivated on Arthrobacter marinus. That is, certain micronutrients that may be lacking in $\underline{A}$. marinus but not in $\underline{P}$. cuprodurans could explain the difference in sensitivity to heat stress when $\underline{E}$. crassus is cultured on these bacteria. The need for trace metals (e.g., iron, magnesium, manganese, zinc and copper by Protozoa) have also been shown to increase sharply with temperature elevations (Hall, 1965). Possibly, in addition to biochemical differences (e.g., utilization of different amino acids, presence or absence of particular vitamins), $\underline{P}$. cuprodurans differs from $\underline{A}$. marinus in elemental composition and these differences are reflected in the thermostability of E. crassus.

Acclimation experiments provide still further evidence for a physiological basis to heat resistance. For example, E. crassus exhibited increased resistance to heat shock when it was cultivated at successively higher temperatures (see 
Fig. 33). Changes in the thermoresistance of Paramecium caudatum accomplished either through acclimation to relatively high temperatures or through "heat hardening" (a short-term shock to high temperatures) were accomplished by changes in resistance to the action of other agents (Irlina, 1967; Poljansky, 1973; and Poljansky \& Sukhanova, 1967). Along with an increase in thermostability, an increase in resistance to ethanol and a decrease in resistance to potassium cyanide was noted. Cold adapted Paranecium exhibited greater resistance to cyanide, but were most sensitive to malonate. Along with resistance to potassium cyanide at low temperatures, they also exhibited high succinic dehydorgenase activity. Thus, changes in thermostability accompanied by changes in sensitivity to inhibitors of respiration and glycolysis when ciliates are acclimated to different temperature regimes indicate that basic metabolic alterations, specifically enzymatic alterations, are occurring simultaneously. In addition to a physiological basis for resistance to thermal stress, genetic and caryonidal differentiation hypotheses have been put forward to account for changes in resistance. In 1887 Dallinger increased the resistance of Tetramitus rostratus and other flagellates to heat by gradually submitting cultures to elevated temperatures up to $70^{\circ} \mathrm{C}$. It is likely that selection played a major role in those experiments (Fauré-Fremiet, 1967; Noland \& Gojdics, 1967). More recently, Poljansky \& Irlina (1973) have shown

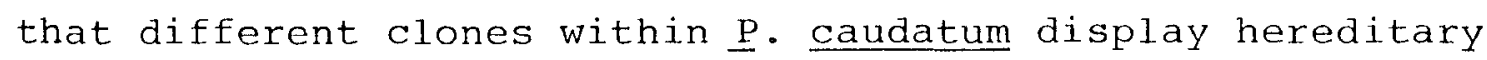


changes in thermostability and that significant interclone differences are seen in the shape of their thermostability curves. It has been suggested that temperature adaptation and resistance to calcium chloride may be examples of differential gene action induced by environmental changes as described by the Jacob \& Monod hypothesis (Preer, 1967). Essentially, this hypothesis asserts that gene action alterations are a result of environmental changes affecting the action of certain repressor substances acting on the genes. Whatever arguments are set forth to explain differences or similarities in tolerances to heat stress among ciliates, the fact remains that thermostability depends upon the physiological state of these organisms, and in turn the physiological condition is under the direct influence of the interaction between the biotic and abiotic factors of the environment.

As stated earlier, environmental impact and the ecological significance of thermal addition have been the bases for much research dealing with resistance adaptation in response to heat stress. Alteration of environmental temperatures, however, may also lead to modifications in competitive interaction. For example, freshwater blue-green algae replace diatoms and other green algae when temperatures are increased from $20^{\circ}$ to $40^{\circ} \mathrm{C}$ (Cairns, 1956). In the presence of other salt marsh organisms (e.g., the nematode, Chromadorina germanica or the foraminiferan, Allogromia laticollaris), Euplotes vannus demonstrates dramatic changes 
in its growth patterns in comparison with its control cultures (Saks et al., 1974). To help explain natural field distribution of ciliates, Hairston \& Kellerman (1965) demonstrated competitive exclusion between two species of Paramecium under a variety of conditions. Paramecium biaurelia (formerly P. aurelia Variety 2; see Sonneborn, 1975) consistently won over P. triaurelia (formerly P. aurelia Variety 3) at low temperatures and low food levels. In the present study, growth rates of ciliates suggest that changes in environmental temperatures could result in changes in the relative dominance of one species at the expense of others (see Fig. 34).

Strombidium sulcatum, Euplotes crassus and E. harpa were selected for an experiment designed to test the effects of culture temperature on growth and survival of 1 - and 2-species cultures. As long as culture temperatures were below those of optimum growth, temperature did not appear to have much influence on competitive interaction between species of ciliates. For example, although inhibited in the presence of one another, due perhaps to the limiting conditions of food and space, a shift in temperature from $15^{\circ}$ to $28^{\circ} \mathrm{C}$ provided no significant advantage to either $\underline{s}$. sulcatum or E. crassus; it only accelerated the final outcome of the experiments (Figs. 35, 36). However, at $30^{\circ} \mathrm{C}$ the influence of temperature becomes evident (Fig. 37). This two-degree increment places E. crassus beyond its limits of efficient growth and it dies out independent of any interaction with S. sulcatum. At this temperature the inhibitory influence 


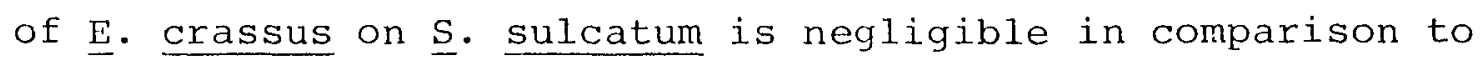
$15^{\circ}$ and $28^{\circ} \mathrm{C}$ experiments (i.e., further elevation in temperature reduces competitive effects of $\underline{E}$. crassus on $\underline{S}$. sulcatum), while the effect of $\underline{S}$. sulcatum on $\underline{E}$. crassus is even less noticeable; i.e., both the control and experimental E. crassus cultures attain similar population densities. At each temperature a noticeable difference in rates of decline between $\underline{E}$. crassus and $\underline{S}$. Sulcatum control cultures is observed; S. sulcatum cultures decline at a faster rate. This suggests that $\underline{S}$. sulcatum is more sensitive to changing culture conditions than E. crassus. Therefore, this is another factor influencing population densities of ciliates operating independently of either temperature or the presence or absence of other ciliates. Although the $30^{\circ} \mathrm{C}$ experiment was not conducted at the higher food level (see Materials and Methods), the differences between the results of the high and low food level experiments at $15^{\circ}$ and $28^{\circ} \mathrm{C}$ are mainly one of total number of organisms produced. There again, the final outcome of the experiment appears to be little influenced by the two temperatures employed (Figs. 38, 39).

The results of the competition experiments between E. Crassus and $\underline{E}$. harpa are not as dramatic as between

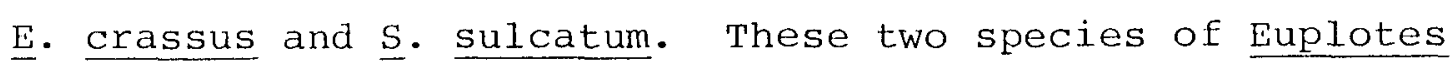
have considerably different generation times throughout their temperature ranges (see Fig. 34) and therefore interaction between them would seem to be reduced. The population growth of one species was unaffected by the presence of the other at 
either $15^{\circ}$ or $28^{\circ} \mathrm{C}$ (Figs. 40, 41). However, although $\underline{E}$. harpa did not attain high densities to begin with, an obvious decline in its experimental cultures (i.e., in the presence of E. crassus) was evident at $15^{\circ} \mathrm{C}$. Similarly, at $28^{\circ} \mathrm{C} \underline{\mathrm{E}}$. crassus began to show indications of inhibition even after E. harpa cultures had expired. One might interpret these observations as a response of the cultures to autotoxins. This is particularly suggestive of E. crassus at $28^{\circ} \mathrm{C}$. However, by this same reasoning control cultures should have declined at similar rates; this was not the case especially with the $15^{\circ} \mathrm{C}$ E. harpa cultures. It is more likely that the decline of $\underline{E}$. harpa at $15^{\circ} \mathrm{C}$ and $\underline{E}$. crassus at $28^{\circ} \mathrm{C}$ is a result of competition for food in mixed cultures, in spite of low numbers and early decline of $\underline{E}$. harpa at $28^{\circ} \mathrm{C}$. Although the data may be insufficient (Fig. 40) or strong enough (Fig. 41) to draw a final conclusion, it appears that $\underline{E}$. crassus may have a competitive edge over E. harpa at $15^{\circ} \mathrm{C}$, but not (or at least less) at $28^{\circ} \mathrm{C}$. The failure of E. harpa to develop at the higher food level may be related to its inability to keep up with too rapid a build up of bacteria and metabolic products under the limited space provided.

In summary, the duration of population growth is a function of temperature and food supply; high temperatures stimulate fast growth and high food concentrations produce greater number of organisms. This is in agreement with previous studies (e.g., Fenchel, 1968b). The magnitude of 
a population is affected by the presence of other ciliates only when temperatures are below optimum values of the interacting species. Such species interaction appears to be one of inhibition due to competition for limited food and space. Beyond temperatures of optimum growth, species interaction becomes negligible. Finally, the rate of decline is related to the physiology of the individual species as well as temperature.

With the exception of Uronema marinum, the ciliates in general adapted readily to temperatures up to $30^{\circ} \mathrm{C}$. Studies with freshwater ciliates show that temperatures for optimum growth range between $25^{\circ}$ and $32^{\circ} \mathrm{C}$ (Phelps, 1946; Prescott, 1957; Propper, 1965; and Thormar, 1962b). This was shown to be true also for the marine ciliate. Diophrys scutum (Fenchel, 1968b). In the present investigation this was observed for the majority of the ciliates studied. Three species, Dexiotricha sp., E. trisulcatus and Tachysoma saltans exhibited slightly higher temperature optima, $33-34^{\circ} \mathrm{C}$ (Table 4 ). Upper thermal limits of significant growth and survival generally were $2-4^{\circ} \mathrm{C}$ higher than temperatures of optimum growth. In shallow water habitats such as New Hampshire tidal marsh pannes, the mean surface and bottom temperatures during the summer months reach up to $28-29^{\circ} \mathrm{C}$ and $27-29^{\circ} \mathrm{C}$, respectively (Kelts, personal communication). The total summer temperature range is approximately $14^{\circ} \mathrm{C}$. During a warm August day (air temperature, $32^{\circ} \mathrm{C}$ ) in a salt marsh panne $20 \mathrm{~cm}$ in depth at Adams Point, New Hampshire, temperatures were as follows. The surface 
registered at $34.5^{\circ} \mathrm{C}$. Immediately below a surface mat of green algae (Cladophora), the temperature was $32-33^{\circ} \mathrm{C}$; the water column was $28-29^{\circ} \mathrm{C}$, and the bottom was $25^{\circ} \mathrm{C}$. Ciliates are therefore well adapted to the usual temperature conditions of these environments.

A sudden increase in ambient water temperature such as occurs at power plant discharge sites, would undoubtedly eliminate the vast majority if not all the ciliates living in the immediate vicinity. Farther from the point of discharge, elevations in temperature may be such as to either eliminate the more sensitive species (e.g., Uronema marinum), chus disrupting normal community succession patterns of the ecosystem, or alter community composition by the imposition of physiological stress on ciliates with lower tolerance limits.

There is no doubt that many factors are involved in the heat sensitivity not only of marine ciliates, but of many other organisms. All act in concert to influence an organism's response to thermal changes. Those examined in the present study are some of the more obvious and perhaps the most significant ecologically. The results reported demonstrate that alteration of these factors (particularly temperature:, whether gradual or sudden, may have a significant affect on the growth and survival of marine ciliates. The information presented should be of interest both from the purely ecological point of view as well as from the more practical applications of environmental quality. 
With the ever increasing demand for energy in the form of electrical power, it is reasonable to assume that increasing numbers of power-generating facilities will be located in coastal areas. Present trends indicate this to be the case. It is hoped that the results of this research, coupled with previous investigations, will further illustrate the need for careful evaluations of both siting and design of such facilities. 


\section{LITERATURE CITED}

Anonymous: Wastes Management Concepts for the Coastal zone: Requirements for Research and Investigation. $126 \mathrm{pp}$ National Academy of Sciences and National Academy of Engineering, Washingtos, D.C. 1970

Bick, H.: Population dynamics of protozoa associated with the decay or organic materials in fresh water. Amer. Zool. 13, 149-160 (1973)

Borror, A. C.: New and little-known tidal marsh ciliates. Trans. Am. microsc. Soc. $84(4), 550-565$ (1965)

--Ecology of interstitial ciliates. Trans. Am. microsc. Soc. $87(2), 233-243(1968)$

---Tidal marsh ciliates (Protozoa): Morphology, ecology, systematics. Acta Protozoologica 10(2), 29-71 (1972)

---Environmental requirements of selected estuarine ciliated protozoa. National Environmental Research Center, Office of Research and Development, U.S. Environmental Protection Agency. Technical Information Service, U.S. Department of Commerce, Springfield, Virginia 1975

Brown, P. J.: Interstitial marsh ciliates. (Abstract) J. Protozool. 20(4), 496 (1973) Burkholder, P. R.: Studies on the nutritive value of Spartina grass growing in the marsh areas of coastal Georgia. Bul1. Torrey bot. Club 83(4), 327-334 (1959) Cairns, Jr., J.: Effects of increased temperatures on aquatic organisms. Indust. Wastes 14), 150-152 (1956) 
---Rate of species diversity restoration following stress in Ereshwater protozoan communities. Univ. Kan. Sci. Bull. $48(6), 209-224$ (1969a)

-- The response of freshwater protozoan communities to heated waste waters. Chesapeake Sci. $10(3,4), 177-185$ (1969b)

-- and G. R. Lanza: The effects of heated waste waters on some microorganisms. $100 \mathrm{pp}$. Water Resources Research Center, Virginia Polytechnic Institute and State Univ., Blacksburg, Virginia (1972)

Clark, J. and W. Brownell: Electric Power Plants in the Coastal Zone: Environmental Issues. American Littoral Society Special Publication No. 7 (1973)

Christophersen, J.: Adaptive temperature responses of microorganisms. In: Molecular Mechanisms of Temperature Adaptation, pp 327-348. Ed. by C. L. Prosser. Publ. No. 84, American Association for the Advancement of Science, Washington, D.C. 1967

-- Basic aspects of temperature action on microorganisms. In: Temperature and Life, pp 3-60. Ed. by H. Precht, J. Christophersen, H. Hensel and W. Larcher. New York: Springer-Verlag 1973

Corliss, J. O.: Silver impregnation of ciliated protozoa by the Chatton-Lwoff technic. Stain Technol. 28, 97-100 (1953)

Coutant, C. C.: Thermal Pollution - Biological Effects: A review of the literature of 1968. J. Water Pollut. Contr. Fed. 41(16), 1036-1053 (1969) 
Crippa-Franceschi, T., M. U. Delmonte-Corrado, P. Ramoino,

G. Mastrangioli-Lavatelli and F. Resta-Zuccarino: Induction and transmission of resistance to high temperature in Paramecium. In: Progress in Protozoology, p 99 (Abstract), IV International Congress on Protozoology, Clermont-Ferrand, France 1973

---and J. Genermont: Physiological adaptations under experimental conditions. Present state of basic knowledge and results. Actualités Protozoologiques. pp 71-85, IV International Congress on Protozoology, Clermont-Ferrand, France 1973

Dallinger, W. H.: The president's address. J. Roy. Micr. Soc. $1,185-199(1887)$

Dingfelder, J. H.: Die Ciliaten vorübergehender Gewässer. Arch. Protistenk. 105, 509-658 (1962)

Dragesco, J.: A propos de Neobursaridium gigas Balech 1941: Sténothermie, inclusions, ultrastructure des trichocytes. Protistologica 4, 157-166 (1968)

Dryl, S.: Response of ciliate protozoa to external stimuli.

Acta Pr:stozoologica 7, 325-333 (1970)

Eckert, R.: Bioelectric control of ciliary activity.

Science $176,473-481$ (1972)

Farrel, J. and A. H. Rose: Temperature effects on microorganisms. In: Thermobiology, pr 147-218. Ed. by A. H. Rose. New York: Academic Press 1967 Fauré-Fremiet, E.: Chemical aspects of ecology. In: Chemical Zoology, Vo1. I, pp 21-54. Ed. by M. Florkin, 
B. T. Scheer and G. W. Kidder. New York: Academic Press 1967

Fenchel, T.: The ecology of marine microbenthos. I. The quantitative importance of ciliates compared with metazoans in various types of sediments. Ophelia $4,121-$ 137 (1967)

---The ecology of marine microbenthos. II. The food of marine benthic ciliates. Ophelia $\underline{5}$, 73-12l (1968a)

---The ecology of marine microbenthos. III. The reproductive potential of ciliates. Ophelia 5, 123-136 (1968b)

---The ecology of marine microbenthos. IV. Structure and function of the benthic ecosystem, its chemical and physical factors and the microfauna communities with special reference to the ciliated protozoa. Ophelia 6, $1-1.82$ (1969)

---Studies on the decomposition of organic detritus derived from the turtle grass Thalassia testudinum. Limnol. Oceanogr. 15, 14-20 (1970)

Frankel, J.: The effects of high temperatures on the pattern of oral development in Tetrahymena pyriformis GL. J. exp. Zool. 155 (3), 403-436 (1964)

Fry, F. E. J.: Responses of vertebrate poikilotherms to temperature. In: Thermobiology, pp 375-409. Ed. by A. H. Rose. New York: Academic Press 1967 Gibbons, J. W. and R. R. Sharitz (Eds.) : Thermal Ecology, Proceeding of the U. S. Atomic Energy Commission Symposium, Augusta, Georgia, May 3-5, 1973. USAEC Technical 
Information Center, Oak Ridge, Tennessee 1974

Giese, A. C.: Differential susceptability of a number of protozoans to ultraviolet radiations. J. Cell Comp. Physiol. 12, 129-138 (1938)

Hairston, N. G. and S. L. Kellerman: Competition between varieties 2 and 3 of Paramecium aurelia: The influence of temperature in a food-limited system. Ecology 46, $134-139$ (1965)

Hall, R. P.: Protozoan Nutrition, 90 pp. New York: Blaisdell Publ. Co. 1965

---Nutrition and growth of protozoa. In: Research in Protozoology, pp 337-405. Ed. by T. T. Chen. New York: Pergamon Press 1967

Hedgpeth, J. W. and J. J. Gonor: Aspects of the potential effect of thermal alteration on marine and estuarine benthos. In: Biological Aspects of Thermal Pollution, pp 80-118. Ed. by P. A. Krenke1 and F. L. Parker. Vanderbilt University Press 1969

Hipke, H. and E. D. Hanson: Induction of temperature sensitivity in Paramecium aurealia by Nitrosoguanidine. J. Protozool. 21(2), 349-352 (1974)

Holz, Jr., G. G.: Nutrition and metabolism of ciliates. In: Biochemistry and Physiology of Protozoa, Vol. 3, pp 199-242. Ed. by S. H. Hutner. New York: Academic Press 1964

---, J. A. Erwin and R. J. Davis: Some physiological characteristics of the mating types and varieties of 
Tetrahymena pyriformis. J. Protozool. 6 (2), 149-156 (1959) Hutchison, R. H.: The effects of certain salts, and of adaptation to high temperatures, on the heat resistance of Paramecium caudatum. J. exp. Zool. 19(2), 211-224 (1915) Hutner, S. H.: The environment and growth: Protozoan origins of metazoan responsitivities. In: Microbial Reaction to Environment, 1lth Symposium of the Society for General Microbiology, Royal Institution, London 1961

Irlina, I. S.: Specific and non-specific changes in resistance of Paramecium caudatum adapted to different temperatures. In: The cell and Environmental Temperature, pp 249-251. Ed. by A. S. Troshin. New York: Pergamon Press 1967

Jahn, T. L. and E. C. Bovee: Motile behavior of protozoa. In: Research in Protozoology, Vol. 1, pp 41-200. Ed. by T. T. Chen. New York: Pergamon Press 1967 James, T. W. and C. P. Read: The effect of incubation temperature on the cell size of Tetrahymena pyriformis. Expl. Cell Res. 13, 510-516 (1957)

Johannes, R. E.: Influence of marine protozoa on nutrient regeneration. Limnol. Oceanogr. 10, 434-442 (1965)

Kasturi Bai, A. R., K. Srihari, M. Shadaksharaswamy and P. S. Jyothy: The effects of temperature on Blepharisma intermedium. J. Protozool. 16(4), 738-743 (1969) Kelts, L.: Personal Communication Kennedy, V. S. and J. S. Mihursky: Bibliography on the effects of temperature in the aquatic environment. Contribution 
No. 326, Natural Resources Institute, Univ. of Maryland 1967

---and---: Upper temperature tolerances of some estuarine bivalves. Chesapeake Sci. 12(4), 193-204 (1971)

Kiesselbach, A.: Der Einfluss erhöhter Temperatur auf Condylostoma arenarium. Arch. Protistenk. 85, 436-442 (1935)

Kinne, O.: The effects of temperature and salinity on marine and brackish water animals. I. Temperature. In: Oceanography and Marine Biology Annual Review, Vol. 1, pp 301-340. Ed. by H. Barnes, London: George Allen and Unwin 1963

---The effects of temperature and salinity on marine and brackish water animals. II. Salinity and temperature salinity combinations. In: Oceanography and Marine Biology Annual Review, Vol. 2, p. 281. Ed. by H. Barnes. London: George Allen and Unwin 1964

---Marine Ecology, Vol. 1, part 1, 681 pp New York: WileyInterscience 1967

Kirby, H.: Some ciliates from salt marshes in California. Arch. Protistenk. 82, 114-133 (1934)

Kitching, J. A.: The physiology of contactile vacuoles: V. The effects of short term variations of temperature on a freshwater peritrich ciliate. J. exp. Biol. 25, $406-420(1948)$

Krenkel, P. A. and F. L. Parker (Eds.): Biological Aspects of Thermal Pollution, 407 pp. Nashville: Vanderbilt Univ. Press 1969 
Lee, C. C. and T. Fenchel: Studies on ciliates associated with sea ice from Antarctica. II. Temperature responses and tolerances in ciliates from Antarctica, temperate and tropical habitats. Arch. Protistenk. 114, 237-244 (1972)

Lee, J. J., J. H. Tietjen, R. J. Stone, W. A. Muller, J. Rullman and M. McEnery: The cultivation and physiological ecology of members of salt marsh epiphytic communities. Helgoländer wiss. Meeresunters. 20, 136-156 (1970)

---, J. H. Tietjen, R. J. Stone, W. A. Muller, M. McEnery, N. Saks, C. Mastropaolo and E. Kennedy: Effects of environmental stress on the community structure, productivity, energy flow, and mineral cycling in salt marsh epiphytic communities. Proceedings of the $3 \mathrm{rd}$ National symposium on Radioecology, Vol. 2, May 10-12, 1971. Oak Ridge, Tennessee 1971

Machemer, H.: Temperature influences on ciliary beat and metachronal coordination in Paramecium. J. Mechanochem. Cell Motility $\underline{\underline{1}}$, 57-66 (1972)

Mcleese, D. W.: Effects of temperature, salinity and oxygen on the survival of the American lobster. J. Fish Res. Bd. Canada 13, 247-272 (1956)

McWhinnie, M. A.: The heat responses of invertebrates (exclusive of insects). In: Thermobiology, pp 353-373. Ed. by A. H. Rose. New York: Academic Press 1967 Murakami, A. and R. Eckert: Cilia: Activation coupled to mechanical stimulation by calcium influx. Science 175, 1375-1377 (1972) 
Noland, L. E. and M. Gojdics: Ecology of free-living protozoa. In: Research in Protozoology, Vol. 2, pp 215-266. Ed. by T. T. Chen. New York: Pergamon Press 1967

Nyberg, D.: Breeding systems and resistance to environmental stress in ciliates. Evolution 28(3), 367-380 (1974)

Odum, W. E.: Utilization of the direct grazing and plant detritus food chains by the striped mullet Mugil cephalus. In: Marine Food Chains, p. 552. Ed. by J. H. Steele. Berkeley and Los Angeles: Univ. of California Press 1970 Phelps, A.: Growth of protozoa in pure culture. III. Effect of temperature upon the division rate. J exp. Zool. 102, $277-292(1946)$

---Thermal adaptations in two strains of the ciliate Tetrahymena geleii. (Abstract) Bull. ecol. Soc. Am. 30, 50 (1949)

Picton, W. L.: Water use in the United States 1900 to 1980 . Water and Sewage Division, U.S. Department of Commerce, Washington, D.C. 1960

Poljansky, G. I.: The problem of physiological adaptation with regard to the forms of variability in free living protozoa (some results and perspectives). In: Progress in Protozoology, pp 40-55. IV International Congress on Protozoology, Clermont-Ferrand, France 1973

---and I. S. Irlina: on the variability in the norm reaction of Paramecium caudatum to various cultivation temperatures. Acta Protozoologica $12(6), 85-95$ (1973) 
and K. M. Sukhanova: Some peculiarities in temperature adaptations of protozoa as compared to multicellular poikilotherms. In: The Cell and Environmental Temperature, pp 200-207. Ed. by A. S. Troshin. New York: Pergamon Press 1967

Preer, Jr., J. R.: Genetics of the protozoa. In: Research in Protozoology, Vol. 3, pp 129-278. Ed. by T. T. Chen. New York: Pergamon Press 1969

Prescott, D. M.: Relation between multiplication rate and temperature in Tetrahymena pyriformis, Strains HS and GL. J. Protozool. 4 , 252-256 (1957) Proceedings of the 2nd Thermal Workshop of the U.S. International Biological Program, J.A. Mihursky and J. B. Pearce (Co-chairmen). Chesapeake Sci. 10 (3,4), 125-341 (1969)

Propper, A.: Différences de sensibilité à la température chez deux variétés de Paramecium caudatum. Archs. zool. exp. gén. 105, 259-271 (1965)

Reid, R., D. Cox, H. Baker and O. Frank: Phytosterols and other lipids as survival factors for Tetrahymena at $0-5^{\circ} \mathrm{C}$. J. Protozool. 16(2), 231-235 (1969)

Rosenbaum, N., J. Erwin, D. Beach and G. G. Holz, Jr.: The induction of a phospholipid requirement and morphological abnormalities in Tetrahymena pyriformis by growth at supraoptimal temperatures. J. Protozool. 13, 535-546 (1966)

Saks, N. M., J. J. Lee, W. A. Muller and J. H. Tietjen: 
Growth of salt-marsh microcosms subjected to thermal

stress. In: Thermal Ecology, pp 391-398. Ed. by

J. W. Gibbons and R. R. Sharitz. IISAEC Technical

Information Center, Oak Ridge, Tennessee 1974

Satir, P.: Ionophore-mediated calcium entry induces mussel

gill ciliary arrest. Science 190, 586-587 (1975)

Sleigh, M. S.: Metachronism and frequency of beat in the peristomal cilia of Stentor. J Exp. Biol. 33, 15-28 (1956)

---Some factors affecting the excitation of contraction

Spirostomum. Acta Protozoologica ㄱ, 335-350 (1970)

Sokal, R. R. and F. J. Rohlf: Biometry, 776 pp. San

Francisco: W. H. Freeman and Co. 1969

Sonneborn, T. M.: The paramecium aurelia complex of fourteen

sibling species. Trans. Am. microsc. Soc. 94(2), 155-178 (1975)

Tawada, K. and H. Miyamoto: Sensitivity of Paramecium thermotaxis to temperature change. J. Protozool. 20(2), $289-292(1973)$

---and F. Oosawa: Responses of Paramecium to temperature change. J. Protozool. 19(1), 53-57 (1972)

Thormar, H.: Cell size of Tetrahymena pyriformis incubated at various temperatures. Expl. Cell Res. 27, 585-586 (1962a)

---Effect of temperature on the reproduction rate of Tetrahymena pyriformis. Expl. Cell Res. 28, 269-279 (1962b) Uhlig, G.: Eine einfache Methode zur Extraktion der vagilen, meopsammalen Mikrofauna. Helgoländer wiss. Meeresunters. 
$\underline{11}(3,4), 178-185(1964)$

Vernberg, F. J. and W. B. Vernberg: The Animal and the Environment, 398 pp New York: Holt Rinehart and Winston, Inc. 1970

---and---: Syngergistic effects of temperature and other environmental parameters on organisms. In: Thermal Ecology, pp 94-99. Ed. by J. W. Gibbons and R. R. Sharitz. USAEC Technical Information Center, Oak Ridge, Tennessee 1974 Vogel, w.: Über die Hitze- und Kälteresistenz von Zoothamnium hiketes Precht (Ciliata, Peritricha). Z. wiss. Zool. 173, $344-378(1966)$

Webb, M.: An ecological study of brackish water ciliates. J. Anim. Ecol. 25, 148-175 (1956)

Wieser, W. and J. Kanwisher: Ecological and physiological studies on marine nematodes from a small salt marsh near Woods Hole, Massachusetts. Limnol. Oceanogr. 6, 262-270 (1961)

Young, R. K. and D. J. Veldman: Introductory Statistics for the Behavioral Sciences, $559 \mathrm{pp}$. New York: Holt Rinehart and Winston, Inc. 1972

ZoBell: C. E.: Studies on marine bacteria. I. The cultural requirements of heterotrophic aerobes. J. mar. Res. $\underline{4}$. $42-75$ (1941) 




-


